Article

\title{
Deoxynivalenol Affects Cell Metabolism and Increases Protein Biosynthesis in Intestinal Porcine Epithelial Cells (IPEC-J2): DON Increases Protein Biosynthesis
}

\author{
Constanze Nossol ${ }^{1, *}$, Peter Landgraf ${ }^{2}$, Stefan Kahlert ${ }^{1}$, Michael Oster ${ }^{3}$, Berend Isermann ${ }^{4}$, \\ Daniela C. Dieterich $^{2,5}$, Klaus Wimmers ${ }^{3}{ }^{-}$, Sven Dänicke ${ }^{6}$ and Hermann-Josef Rothkötter ${ }^{1}$ \\ 1 Medical Faculty, Institute of Anatomy, Otto-von-Guericke University, 39120 Magdeburg, Germany; \\ stefan.kahlert@med.ovgu.de (S.K.); hermann-josef.rothkoetter@med.ovgu.de (H.-J.R.) \\ 2 Institute for Pharmacology and Toxicology, Otto-von-Guericke University, 39120 Magdeburg, Germany; \\ peter.landgraf@med.ovgu.de (P.L.); daniela.dieterich@med.ovgu.de (D.C.D.) \\ 3 Genomics Unit, Leibniz Institute for Farm Animal Biology, 18196 Dummerstorf, Germany; \\ oster@fbn-dummerstorf.de (M.O.); wimmers@fbn-dummerstorf.de (K.W.) \\ 4 Institute of Clinical Chemistry and Pathochemistry, Otto-von-Guericke University, 39120 Magdeburg, \\ Germany; berend.isermann@med.ovgu.de \\ 5 Center for Behavior Brain Sciences (CBBS), 39120 Magdeburg, Germany \\ 6 Institute of Animal Nutrition, Friedrich-Loeffler Institute, 38116 Braunschweig, Germany; \\ Sven.Daenicke@fli.de \\ * Correspondence: constanze.nossol@med.ovgu.de; Tel.: +49-391-672-1930; Fax: +49-391-671-3630
}

Received: 2 August 2018; Accepted: 6 November 2018; Published: 9 November 2018

\begin{abstract}
Deoxynivalenol (DON) is a toxin found in cereals as well as in processed products such as pasta, and causes substantial economic losses for stock breeding as it induces vomiting, reduced feeding, and reduced growth rates in piglets. Oxidative phosphorylation, TCA-cycle, transcription, and translation have been hypothesized to be leading pathways that are affected by DON. We used an application of high and low glucose to examine oxidative phosphorylation and anaerobic glycolysis. A change in the metabolic status of IPEC-J2 was observed and confirmed by microarray data. Measurements of oxygen consumption resulted in a significant reduction, if DON attacks from the basolateral. Furthermore, we found a dose-dependent effect with a significant reduction at $2000 \mathrm{ng} / \mathrm{mL}$. In addition, SLC7A11 and PHB, the genes with the highest regulation in our microarray analyses under low glucose supply, were investigated and showed a variable regulation on protein level. Lactate production and glucose consumption was investigated to examine the impact of DON on anaerobic glycolysis and we observed a significant increase in $2000 \mathrm{bl} \mathrm{bigh}^{\text {high }}$ and a decrease in 2000 $\mathrm{ap}^{\text {high }}$. Interestingly, both groups as well as $200 \mathrm{bl}^{\text {high }}$ showed a significant higher de novo protein synthesis when compared to the control. These results indicate the direct or indirect impact of DON on metabolic pathways in IPEC-J2.
\end{abstract}

Keywords: microarray analyses; toxins; DON; BONCAT; cell metabolism; oxygen; IPEC-J2

Key Contribution: In our study, we used the BONCAT method to analyze to de novo protein synthesis. We observed a significant higher protein synthesis under the low DON concentration of $200 \mathrm{ng} / \mathrm{mL} \mathrm{bl}$ as well as under high DON concentrations of $2000 \mathrm{ng} / \mathrm{mL}$ ap and bl [high glucose conditions].

\section{Introduction}

Deoxynivalenol (DON) is a toxin, which is produced by Fusarium graminearum and Fusarium culmorum in oats, maize, barley, and wheat. In fact, DON is not the most common toxin, but it is found 
in crops, and used for food and feed production in Europe and North America [1]. Moreover, DON has been detected as a contaminant in processed products including popcorn, pasta, and beer. Schothorst and Jekel detected a concentration of $200 \mathrm{ng} / \mathrm{mL}(0.675 \mu \mathrm{M})$ DON in their beer samples [2].

Critically, DON causes substantial economic losses for stock breeding as it induces vomiting, reduced feeding, and reduced growth rates in piglets [3]. However, the mechanisms underlying these toxicological effects are still unclear. DON affects the immune system and gastrointestinal tract via disruption of the intestinal barrier function and regulation of nutrient transporter gene expression although the effects are not consistent [4-7]. Several studies have shown that DON inhibits barrier function and induces the proinflammatory gene expression of TNF $\alpha$, IL-6, and IL-1ß. In vitro, it affects membrane integrity depending on dose, cell line, and exposure time [8-11]. Furthermore, it has been shown that DON is an inhibitor of protein biosynthesis [3] and that it interferes with the peptidyl transferase function of ribosomes, thereby impairing initiation and elongation [12]. In an in vivo study, Dänicke et al. showed significantly reduced protein synthesis (fractional synthesis rate (FSR)) in the kidneys, spleen, and ileum of DON-exposed pigs, but jejunum and jejunal mucosa cells were not affected by DON [13].

Deoxinivalenol influences gene expression and therefore different pathways are affected: TCA-cycle, oxidative phosphorylation, transcription, and translation [8]. Deoxynivalenol affects protein biosynthesis due to the activation of ribosomal-associated kinase PKR. The ribosome-associated kinase PKR phosphorylates eIF2 $\alpha$ and inhibits translation [14]. Possibly, mitochondria are an important target of DON because oxidative phosphorylation takes place in mitochondria. Mitochondria are the most important tool to convert pyruvate to $\mathrm{CO}_{2}$ and $\mathrm{H}_{2} \mathrm{O}$ in oxidative phosphorylation. Anaerobic glycolysis is used under hypoxic conditions or during proliferation, whereas pyruvate is converted to lactate (no mitochondria is used). Glucose is the most essential substrate in cell culture and is used for both oxidative phosphorylation and anaerobic glycolysis, but cells can be forced to use glutamine if glucose is restricted. Mitochondria generate a high amount of ATP due to the respiratory chain, and play an important role in a wide variety of intracellular processes including signal transduction and protein synthesis. Additionally, different studies have shown that trichothecene toxins induce oxidative stress [15-17] due to a significantly increased level of reactive oxygen species (ROS) and the depletion of intracellular reduced glutathione (GSH). Mitochondria-generated ROS play an important role in cytochrome $\mathrm{C}$ release and other pro-apoptotic proteins, which can trigger caspase activation and apoptosis [17].

Important morphological features indicating an adequate gut epithelial cell culture model are the development of highly prismatic enterocytes as the monolayer, polarized cell growths with a well-defined apical and basolateral cell membrane compartment, microvilli on the apical side, expression of lateral tight junction complexes enabling the epithelial barrier function, and desmosomes and zonula adhaerens between the epithelial cells [18,19]. Furthermore, a metabolic pathway close to the in vivo situation is an important feature. A technical prerequisite is a monolayer support (comparable with the epithelial basement membrane) with pores. Within many various continuous cell lines, IPEC-J2 provides an exceptional option, as it is both originally isolated from newborn piglets and is non-transformed, and not tumor derived. IPEC-J2 shows a morphological and functional similarity to porcine enterocytes. This cell line represents a well-established model for the simulation of the human intestinal barrier [20].

The aim of this study was to establish a culture model where studying oxidative phosphorylation and anaerobic glycolysis was possible. Furthermore, we wanted to demonstrate the impact of DON on both pathways and on de novo protein synthesis. 


\section{Results}

\subsection{Constitutively Regulated Genes Depend on High Or Low Glucose Concentration}

In Figure 1, the comparisons of 2000 ap high vs. $2000 \mathrm{ap}^{\text {low }}, 2000 \mathrm{bl}^{\text {high }}$ vs. $2000 \mathrm{bl}^{\text {low }}, 200 \mathrm{ap}^{\text {high }}$ vs. $200 \mathrm{ap}^{\text {low }}$, and $200 \mathrm{bl}^{\text {high }}$ vs. $200 \mathrm{bl}^{\text {low }}$ are shown. Overall, 8869 genes were significantly regulated. In the comparison of intersections, we found 2610 genes, which were commonly regulated in all comparisons and named as basically or constitutively regulated genes (red marked in Figure 1). Therefore, 1529 were generally up-regulated and 1081 were down-regulated. In the next step, 2610 genes were used for the analyses with theDatabase for Annotation, Visualization and Integrated Discovery (DAVID) and resulted in the following pathways (first 5): (I) Metabolic pathways, (II) Pathways in cancer, (III) Endocytosis, (IV) PI3K-Akt, and (V) Biogenesis of antibiotics. Metabolic pathways were significantly affected, with the highest number of regulated genes (151; Table 1). With the focus on these 2610 basically regulated genes, four different genes were found in the pairwise comparisons with the highest down- or up-regulation: TXNIP (thioredoxin interacting protein), MEST (mesoderm-specific transcript homolog protein), CYP26B1 (cytochrome P450 26B1), and TAGLN (transgelin) (Figure 2A). TXNIP was found to be down-regulated in all treatment groups ${ }^{\text {low }}$ when compared to high glucose (Figure 2A). Furthermore, the data of the microarray analyses were confirmed by qPCR (Figure 2B), and we observed a significant down-regulation in all treatment groups of low glucose when compared to the appropriate treatment group under high glucose. In our Western blot analyses, no TXNIP protein was found in all treatment groups ${ }^{\text {low }}$ as well as in the control ${ }^{\text {low }}$ cells (Figure $2 \mathrm{C}$ ) under low glucose conditions. In addition, we analyzed our data by qPCR. Furthermore, a significant up-regulation of TXNIP when compared to control was observed at 2000 ap independent of glucose concentration (Table 2). Under high glucose conditions, we detected a strong expression at 2000 ap when compared to the control, but not under low glucose conditions (Figure 2C).

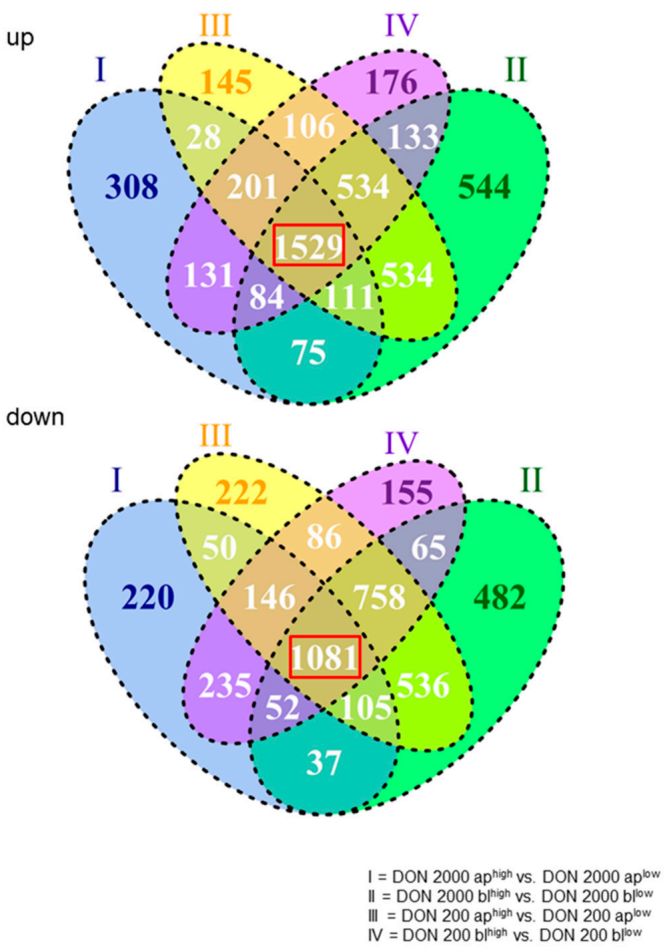

Figure 1. Microarray analyses of deoxynivalenol (DON)-treatment groups dependent on glucose concentration. All significantly regulated genes were analyzed due to a comparison of intersections. A total of 1529 genes were constitutively up-regulated and 1081 were constitutively down-regulated (sum: 2610; red marked; $N=3$ ). 
Table 1. Significantly regulated pathways. All genes were analyzed via DAVID and resulted in significantly regulated KEGG-pathways. All basically regulated (red marked in Figure 1) genes in the comparison of high and low glucose under impact of DON were examined.

\begin{tabular}{cc}
\hline Number & Pathways \\
\hline 1 & Metabolic pathways \\
2 & Pathways in cancer \\
3 & Endocytosis \\
4 & PI3K-Akt signaling pathway \\
5 & Biosynthesis of antibiotics \\
\hline
\end{tabular}

A

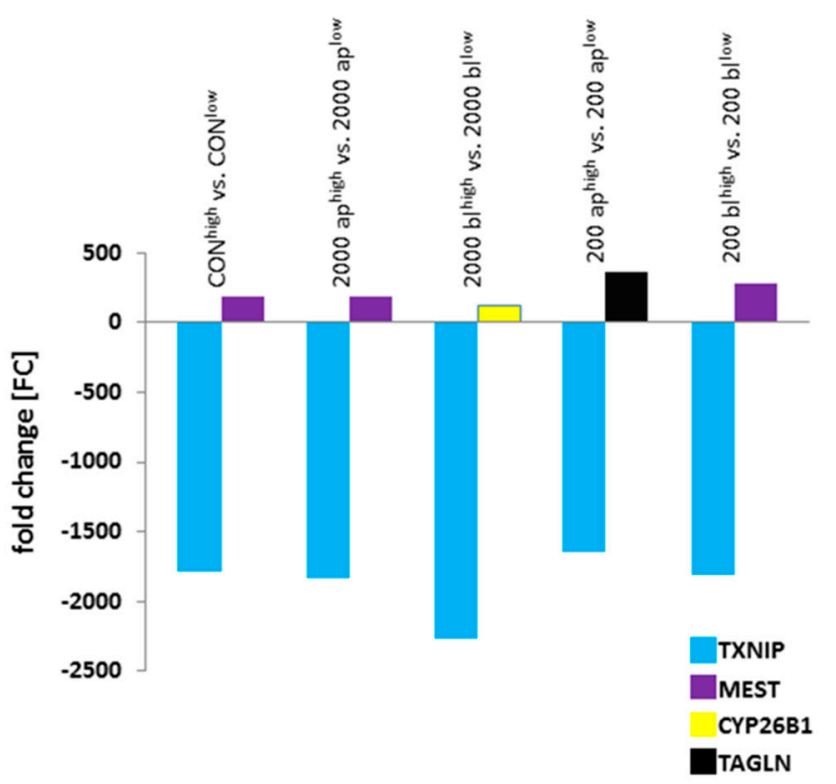

B

\begin{tabular}{lll}
\hline & $18 \mathrm{~S}$ & B-actin \\
\hline CONhigh vs. CON & $43.93^{* * *}$ & $40.61^{* * *}$ \\
2000 aphigh vs. 2000 aplow & $74.31^{*}$ & $31.54^{* * *}$ \\
2000 blhigh vs. 2000 blow & $39.25^{* * *}$ & $41.75^{* * *}$ \\
200 aphigh vs. 200 aplow & $33.6^{* * *}$ & $35.52^{* * *}$ \\
200 blhigh vs. 200 blow & $44.75^{* * *}$ & $38.78^{* * *}$ \\
\hline
\end{tabular}

C

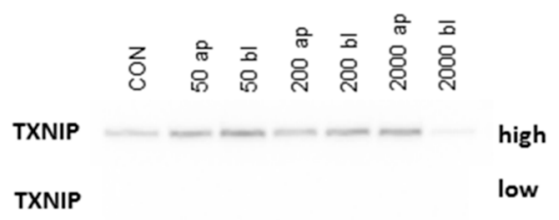

Figure 2. Constitutively regulated genes of the microarray analyses. (A) 2610 genes were basically up- or down-regulated in the pairwise comparison of DON-treatment groups dependent on glucose concentration in the microarray analyses. The highest up- and down-regulated genes in the pairwise comparisons within the pool of basically regulated genes are shown: TXNIP (thioredoxin interacting protein), MEST (mesoderm specific transcript), CYP26B1 (cytochrome P450 family 26 subfamily B member 1), and TAGLN (transgelin). (B) qPCR data [relative quantification; \%] of TXNIP are shown in the table $(N=5)$. All comparisons resulted in a significant down-regulation in DON-treatment groups under low glucose when compared to the appropriate treatment group under high glucose $\left(p<0.05^{*}\right.$; $\left.p<0.001^{* * *}\right)$. (C) A reduction of TXNIP was found on protein level in all DON-treatment groups under low glucose when compared to the equivalent group of high glucose $(N=3)$. 
Table 2. Analyzed genes via qPCR $(N=5)$. Different genes were analyzed with qPCR, which were related to metabolic pathways: TXNIP, COX5B, GLUT1, MCT1, SGLT1, PHB and SLC7A11. All comparisons were examined under low and high glucose. Therefore, $18 \mathrm{~S}$ and actin were used as housekeeping genes. All comparisons were examined under low and high glucose. All treatment groups (50 ap; $50 \mathrm{bl} ; 200 \mathrm{ap} ; 200 \mathrm{bl}, 2000 \mathrm{ap}$ and $2000 \mathrm{bl}$ ) were compared to the control [CON = 100\%] and significantly regulated genes were asterisked $\left(p<0.05^{*} ; p<0.001^{* *} ; p<0.001^{* * *}\right)$. The values shown in the table represent relative quantification [\%].

\begin{tabular}{|c|c|c|c|c|}
\hline & \multicolumn{4}{|c|}{ TXNIP } \\
\hline & \multicolumn{2}{|c|}{$18 \mathrm{~S}$} & \multicolumn{2}{|c|}{ Actin } \\
\hline & Low & High & Low & High \\
\hline $\mathrm{CON}$ & 100 & 100 & 100 & 100 \\
\hline 50 ap & 109.68 & 112.25 & 138.83 & $128.94 *$ \\
\hline $50 \mathrm{bl}$ & 100.46 & 115.4 & 123.68 & 130.74 * \\
\hline 200 ap & 86,65 & 113.29 & 113.81 & 130.13 * \\
\hline $200 \mathrm{bl}$ & 125.99 & 123.68 & 127.16 & 133.18 * \\
\hline 2000 ap & $216.1^{* * *}$ & 127.75 & $110.33^{*}$ & $142.08^{*}$ \\
\hline \multirow[t]{4}{*}{$2000 \mathrm{bl}$} & 111.03 & 124.26 & 96.82 & $94.17^{* * *}$ \\
\hline & \multicolumn{4}{|c|}{ COX5B } \\
\hline & \multicolumn{2}{|c|}{$18 S$} & \multicolumn{2}{|c|}{ Actin } \\
\hline & Low & High & Low & High \\
\hline $\mathrm{CON}$ & 100 & 100 & 100 & 100 \\
\hline 50 ap & 102.34 & 89.09 & 129.53 & 102.45 \\
\hline $50 \mathrm{bl}$ & 105.6 & 92.02 & 127.62 & 104.36 \\
\hline 200 ap & 85.86 & 96.37 & 112.77 & 110.82 \\
\hline $200 \mathrm{bl}$ & 109.18 & 89.09 & 110.19 & 96.03 \\
\hline 2000 ap & $242^{* * *}$ & 144.47 & $125.12^{* * *}$ & $158.91^{* * * *}$ \\
\hline \multirow[t]{4}{*}{$2000 \mathrm{bl}$} & 172.4 & $140.03^{* * *}$ & 149.48 & 105.92 \\
\hline & \multicolumn{4}{|c|}{ GLUT1 } \\
\hline & \multicolumn{2}{|c|}{$18 S$} & \multicolumn{2}{|c|}{ Actin } \\
\hline & Low & High & Low & High \\
\hline $\mathrm{CON}$ & 100 & 100 & 100 & 100 \\
\hline 50 ap & 127.16 & 91.59 & $160.96^{* *}$ & 105.21 \\
\hline $50 \mathrm{bl}$ & 126.58 & 97.72 & $155.83^{* *}$ & 110.7 \\
\hline 200 ap & 119.75 & 138.84 & $157.28^{* *}$ & 159.48 * \\
\hline $200 \mathrm{bl}$ & 150.18 & 115.4 & $151.57 *$ & 124.26 \\
\hline 2000 ap & $460.01^{* * *}$ & $891.61^{* * *}$ & $237.84^{* * *}$ & $985.62 * * *$ \\
\hline \multirow[t]{4}{*}{$2000 \mathrm{bl}$} & $688.67^{* * *}$ & $483.44^{* * *}$ & $591.46^{* * *}$ & $366.38^{* * * *}$ \\
\hline & \multicolumn{4}{|c|}{ MCT1 } \\
\hline & \multicolumn{2}{|c|}{$18 S$} & \multicolumn{2}{|c|}{ Actin } \\
\hline & Low & High & Low & High \\
\hline $\mathrm{CON}$ & 100 & 100 & 100 & 100 \\
\hline 50 ap & 115.94 & 85.46 & $146.75^{* * *}$ & 94.95 \\
\hline $50 \mathrm{bl}$ & 119.27 & 88.27 & $145.4^{* * *}$ & 96.72 \\
\hline 200 ap & 93.74 & 92.99 & 123.11 & 104.56 \\
\hline $200 \mathrm{bl}$ & 99.08 & 88.27 & 100 & 91.93 \\
\hline 2000 ap & $194.08 *$ & 112.8 & 99.66 & 125.58 \\
\hline $2000 \mathrm{bl}$ & 154.3 & 100 & $133.79^{* *}$ & 73.3 \\
\hline
\end{tabular}


Table 2. Cont.

\begin{tabular}{|c|c|c|c|c|}
\hline & \multicolumn{4}{|c|}{ SGLT1 } \\
\hline & \multicolumn{2}{|c|}{$18 S$} & \multicolumn{2}{|c|}{ Actin } \\
\hline & Low & High & Low & High \\
\hline $\mathrm{CON}$ & 100 & 100 & 100 & 100 \\
\hline 50 ap & 118.65 & 107.14 & $150.18^{* * *}$ & 123.32 \\
\hline $50 \mathrm{bl}$ & 123.11 & 114.87 & $151.57^{* * *}$ & 130.13 \\
\hline 200 ap & 88.68 & 80.8 & 116.47 & 92.08 \\
\hline $200 \mathrm{bl}$ & 118.41 & 108.21 & 117.98 & 118.53 \\
\hline 2000 ap & $176.23^{* *}$ & 78.43 & 85.75 & 90.27 \\
\hline \multirow[t]{4}{*}{$2000 \mathrm{bl}$} & 81.78 & 62.2 & $67.43^{* * *}$ & $46.12^{* * *}$ \\
\hline & \multicolumn{4}{|c|}{ РHB } \\
\hline & \multicolumn{2}{|c|}{$18 S$} & \multicolumn{2}{|c|}{$\beta$-actin } \\
\hline & Low & High & Low & High \\
\hline $\mathrm{CON}$ & 100 & 100 & 100 & 100 \\
\hline 50 ap & 127.16 & 91.59 & 160.96 & 105.21 \\
\hline $50 \mathrm{bl}$ & 126.58 & 97.72 & 155.83 & 110.7 \\
\hline 200 ap & 119.75 & 138.84 & 157.28 & 159.48 \\
\hline $200 \mathrm{bl}$ & 150.18 & 115.4 & 151.57 & 124.26 \\
\hline 2000 ap & $460.01^{* * *}$ & $891.61^{* * *}$ & $237.84^{* * *}$ & $985.62 * * *$ \\
\hline \multirow[t]{4}{*}{$2000 \mathrm{bl}$} & $688.67^{* * *}$ & $483.439^{* * *}$ & $591.46^{* * *}$ & $366.38^{* * *}$ \\
\hline & \multicolumn{4}{|c|}{ SLC7A11 } \\
\hline & \multicolumn{2}{|c|}{$18 S$} & \multicolumn{2}{|c|}{$\beta$-actin } \\
\hline & Low & High & Low & High \\
\hline $\mathrm{CON}$ & 100 & 100 & 100 & 100 \\
\hline 50 ap & 127.75 & 110.19 & 161.7 & 126.58 \\
\hline $50 \mathrm{bl}$ & 126.99 & 136.29 & 153.48 & $154.4^{* * *}$ \\
\hline 200 ap & 92.87 & 84.67 & 121.98 & 97.27 \\
\hline $200 \mathrm{bl}$ & 97.72 & 108.17 & 98.62 & 116.47 \\
\hline 2000 ap & $30.57^{* * *}$ & 62.31 & $15.8^{* * *}$ & $68.87^{* *}$ \\
\hline $2000 \mathrm{bl}$ & $31.59^{* * *}$ & 92.02 & $28.32 * * *$ & 69.74 \\
\hline
\end{tabular}

\subsection{General Effect of DON on Gene Expression under Low Glucose Consumption}

In the IPEC-J2 microarray analyses, 3817 genes were significantly up-regulated and 3412 genes were significantly down-regulated in the comparison of $\mathrm{CON}^{\text {low }}$ vs. 2000 ap ${ }^{\text {low }}, \mathrm{CON}^{\text {low }}$ vs. $2000 \mathrm{bl}^{\text {low }}$, $\mathrm{CON}^{\text {low }}$ vs. $200 \mathrm{ap}^{\text {low }}$, and $\mathrm{CON}^{\text {low }}$ vs. $200 \mathrm{bl}^{\text {low }}$. In Figure 3, the intersections of the up-regulated as well as all of the down-regulated genes are shown between the different comparisons. There were 152 genes that were basically up-regulated independent of the DON concentration (red marked in Figure 3), whereas 34 genes were generally down-regulated (red marked in Figure 3). These genes were significantly regulated on principle with DON-impact. Significantly regulated genes (186) were analyzed with DAVID and resulted in only five KEGG-pathways: (I) Spliceosome, (II) RNA transport, (III) Epstein-Barr virus infection, (IV) Ribosome biogenesis in eukaroytes, and (V) mRNA surveillance pathway (Table 3).

In the next step, we looked for the highest up- and down-regulated genes within the pool of basically regulated genes (186) in the pairwise comparisons of the microarray analyses (Figure 4A). SLC7A11 and PHB were the most common, which were significantly regulated. SLC7A11 was significantly down-regulated in the treatment groups of 2000 ap and bl when compared to the control. This was confirmed by qPCR (18S: Kruskal-Wallis; $p<0.001$; Mann-Whitney Test; Figure 4B). Furthermore, we analyzed our data with a second housekeeper of $\beta$-actin and observed the same results (Kruskal-Wallis, $p<0.001$; Mann-Whitney Test). In addition, 200 ap and $200 \mathrm{bl}$ also showed a significant decrease in the microarray analyses, but not in qPCR (Figure 4B). In addition, we also examined 
SLC7A11 under high glucose consumption and found a significant reduction of the expression under 2000 ap, but not in 2000 bl (18S: ANOVA, F $(6 ; 96)=4.811 ; p<0.001$; Table 2$)$. The same result was detected using $\beta$-actin (Kruskal-Wallis Test, $p<0.001$; Mann-Whitney Test).
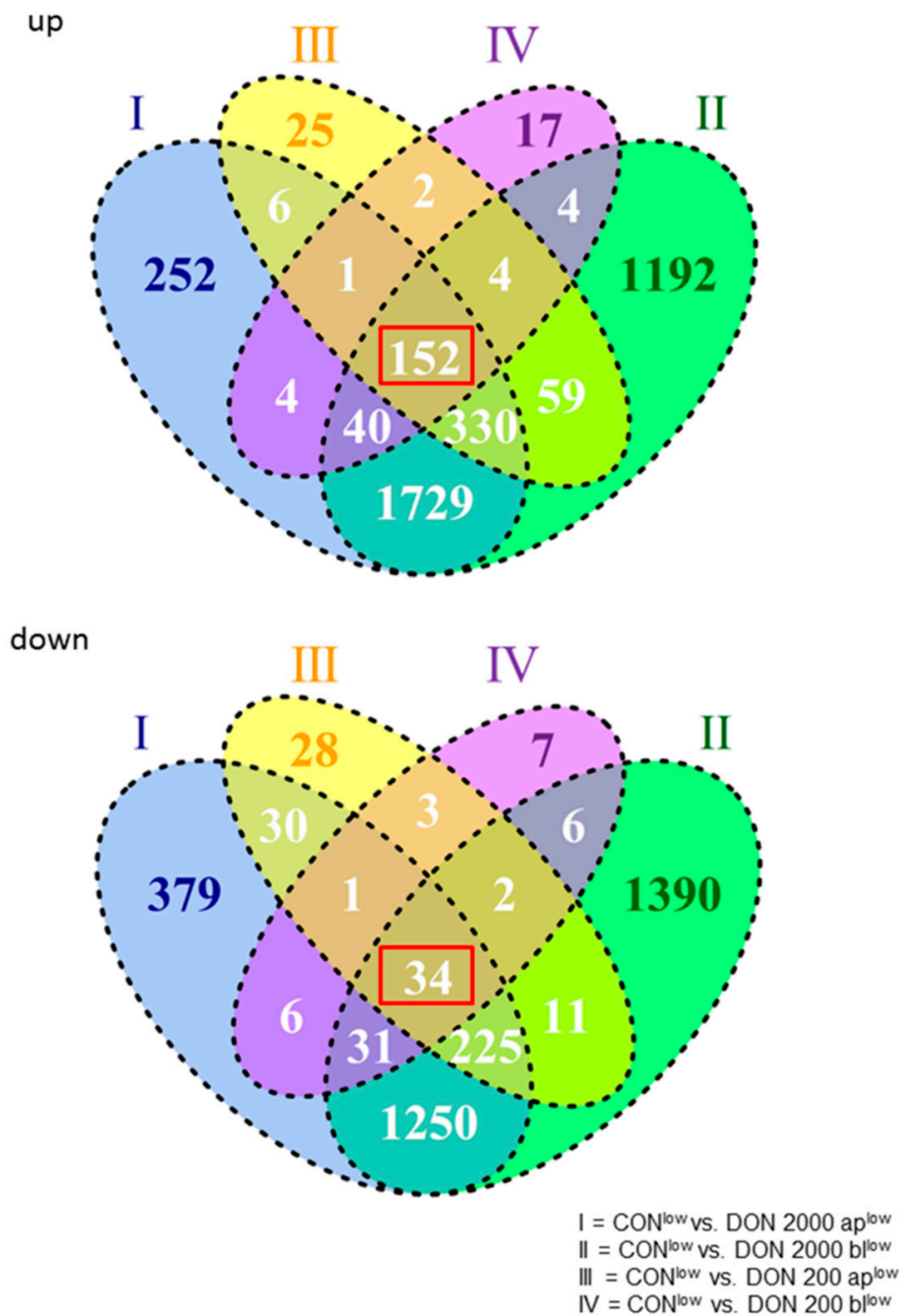

Figure 3. Microarray analyses of DON-treatment groups in comparison to the control under low glucose conditions. A total of 3817 genes were significantly regulated. With the focus on basically regulated genes, we found 152 genes that were up-regulated and 34 genes that were down-regulated (red marked; $N=3$ ).

Table 3. Significantly regulated pathways under low glucose conditions. A total of 186 genes (red marked in Figure 3) that were significantly regulated in the comparisons between the control and DON treatment groups under low glucose were analyzed. The analyses with DAVID resulted in significantly regulated KEGG-pathways.

\begin{tabular}{cc}
\hline Number & Pathways \\
\hline 1 & Spliceosomes \\
2 & RNA transport \\
3 & Epstein-Barr virus infection \\
4 & Ribosome biogenesis in eukaryotes \\
5 & mRNA surveillance pathway \\
\hline
\end{tabular}




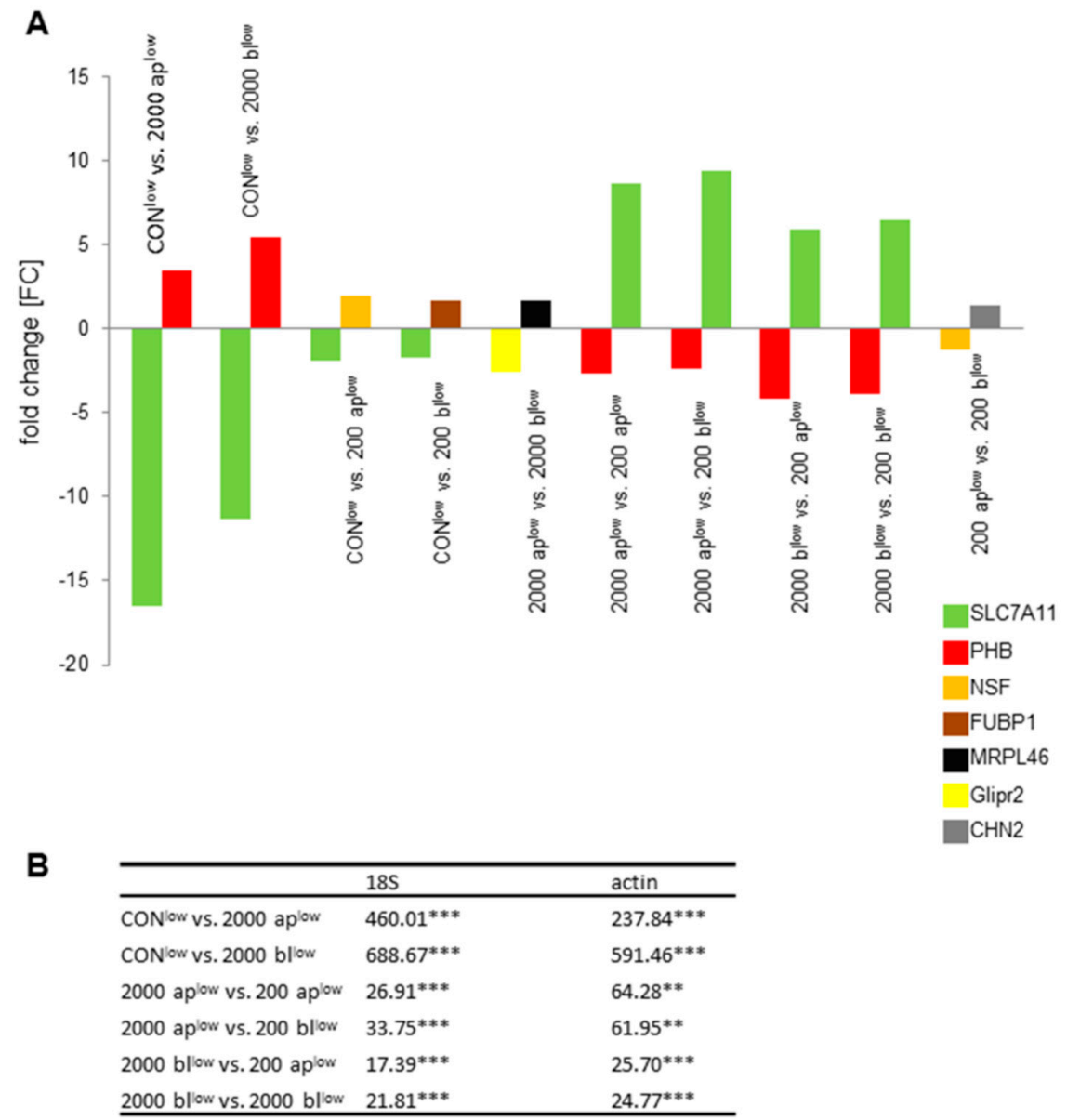

C

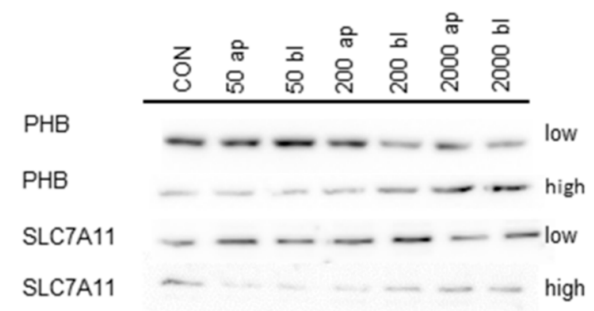

Figure 4. Basic regulated genes. A total of 186 genes were basically up- or down-regulated in the pairwise comparison of the DON-treatment group under low glucose concentration. The highest up- and down-regulated genes in the pairwise comparisons within the pool of basically regulated genes are shown (A). SLC7A11 (glutamate transporter) and PHB (Prohibitin) were the most frequently occurring genes in the comparisons. Therefore, SLC7A11 and PHB were analyzed via qPCR (relative quantification [\%]; $N=5)$. Comparisons that were significantly regulated were asterisked $(p<0.01 * *$, $\left.p<0.001^{* * *}\right)(\mathbf{B})$, and Western blot $(N=3)$ analysis was performed $(\mathbf{C})$. PBH showed a contrarian gradient in the expression depending on glucose consumption, DON-concentration, and application.

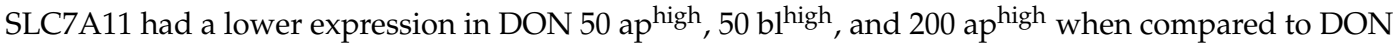
$50 \mathrm{ap}^{\text {low }}, 50 \mathrm{bl}^{\text {low }}$, and $200 \mathrm{ap}^{\text {low }}$.

PHB expression was tested due to $\mathrm{QPCR}$ and showed a significant up-regulation in the microarray data (Figure 4A) as well as in qPCR in the comparison of CON ${ }^{\text {low }}$ and 2000 ap ${ }^{\text {low }}$ $\left(p<0.001\right.$; Mann-Whitney test), respectively $\mathrm{CON}^{\text {low }}$ and $2000 \mathrm{bl}^{\text {low }}(p<0.001$; Mann-Whitney test) (Kruskal-Wallis test; $p<0.001 ; 18 S$; Figure 4B). The same results were confirmed by $\beta$-actin (Kruskal-Wallis test, $p<0.001$ ). In addition, in Western Blot analyses a lower PHB content was 
found in $200 \mathrm{bl}^{\text {low }}, 2000 \mathrm{ap}^{\text {low }}$ and $2000 \mathrm{bl}^{\text {low }}$ compared to control (Figure 4C). Furthermore, PHB was generally down-regulated in 200 DON-treatment groups when compared to 2000 DON-treatments groups (Figure 4B). In a further analysis, we investigated the effect of DON under high glucose supply (Table 2). Under high glucose supply, we also observed a significant up-regulation in 2000 ap $(p<0.001$; Mann-Whitney test) and $2000 \mathrm{bl}(p<0.001$; Mann-Whitney test) with both housekeeping genes (both: Kruskal-Wallis test; $p<0.001$; Figure 4B) when compared to the control.

\subsection{Effect of Glucose Concentration on Oxygen Consumption}

IPEC-J2 was analyzed with the focus on glucose dependent oxygen consumption. IPEC-J2 $\left(40.76 \mathrm{nmol} / \mathrm{L} \times 10^{5}\right.$ cells) cultured under low glucose conditions showed a significantly higher ( 2 fold higher; $p<0.001$ ) oxygen consumption than the IPEC-J2 growing under high glucose content $\left(22.54 \mathrm{nmol} / \mathrm{L} \times 10^{5}\right.$ cells; Figure 5).

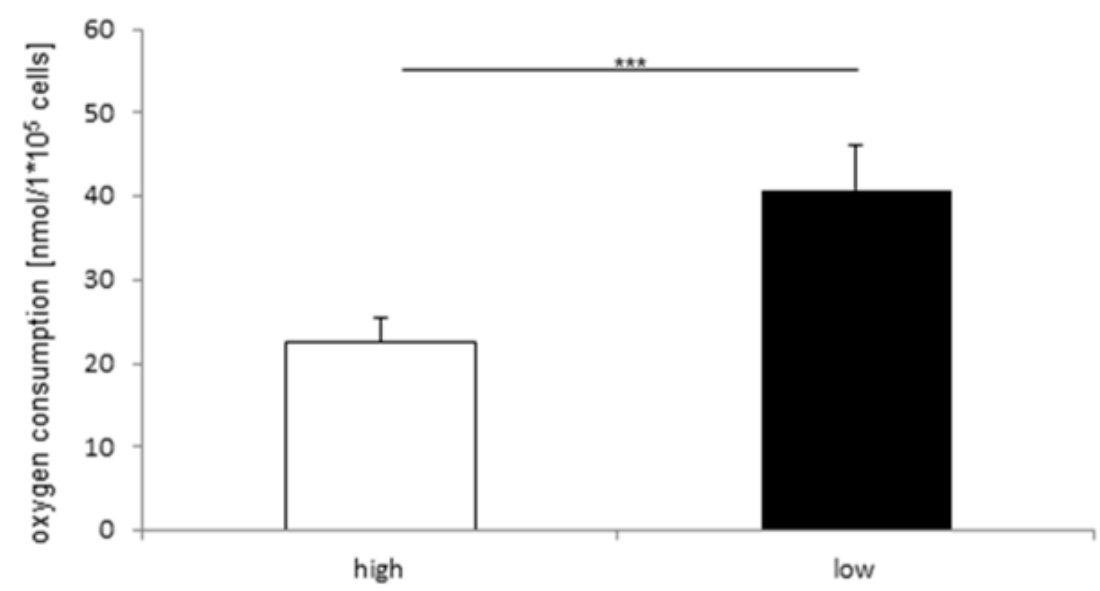

Figure 5. Oxygen consumption under high and low glucose concentration $(N=5)$. Oxygen consumption was measured under high and low glucose conditions. Under low glucose concentration, a higher oxygen consumption was observed than under high glucoses concentration (high: $22.54 \mathrm{nmol} / \mathrm{L} \times 10^{5}$ cells; low: $40.76 \mathrm{nmol} / \mathrm{L} \times 10^{5}$ cells, $\left.{ }^{* * *} p<0.001\right)$.

\subsection{Influence of DON-Application on Oxygen Consumption}

To analyze the possible effect of the application side, all data were sorted into the control, apical, and basolateral. This resulted in a slight, but not significant, decrease of the apical when compared to the control (control: $38.85 \mathrm{nmol} / \mathrm{L} \times 10^{5}$ cells; apical: $30.60 \mathrm{nmol} / \mathrm{L} \times 10^{5}$ cells) and showed a significant reduction of the basolateral when compared to the control (basolateral: $28.68 \mathrm{nmol} / \mathrm{L} \times$ $10^{5}$ cells; Figure 6A).

\subsection{Oxygen Consumption and DON-Concentration}

Furthermore, we examined the effect of DON concentration on oxygen consumption. A significant decrease was detected in the comparison of the control $\left(38.85 \mathrm{nmol} / \mathrm{L} \times 10^{5}\right.$ cells $)$ and DON 2000 $\left(26.34 \mathrm{nmol} / \mathrm{L} \times 10^{5}\right.$; Kruskal-Wallis test, $p=0.01$; Mann-Whitney test, $p=0.003$; Figure 6B). Additionally, we tested different DON concentrations combined with the two different applications of apical and basolateral. No significant differences were detected under low glucose, but a marked increase at $50 \mathrm{bl}$ (Figure 6C). Under high glucose (Welch ANOVA, $p=0.004$; Games Howell; Figure 6C), a trend of reduced oxygen consumption was observed in the comparisons between the control and DON-treatment groups: 50 ap $\left(19.16 \mathrm{nmol} / \mathrm{L} \times 10^{5}\right.$ cells; $\left.p=0.089\right), 50 \mathrm{bl}\left(19.23 \mathrm{nmol} / \mathrm{L} \times 10^{5}\right.$ cells; $p=0.088), 200 \mathrm{ap}\left(16.4 \mathrm{nmol} / \mathrm{L} \times 10^{5}\right.$ cells; $\left.p=0.051\right)$, and $200 \mathrm{bl}\left(17.46 \mathrm{nmol} / \mathrm{L} \times 10^{5} ; p=0.062\right)$. A significant difference was observed between CON vs. 2000 ap $(p=0.047), 200$ ap vs. $2000 \mathrm{bl}$ $(p=0.035)$, and 2000 ap and $2000 \mathrm{bl}(p=0.016)$ 


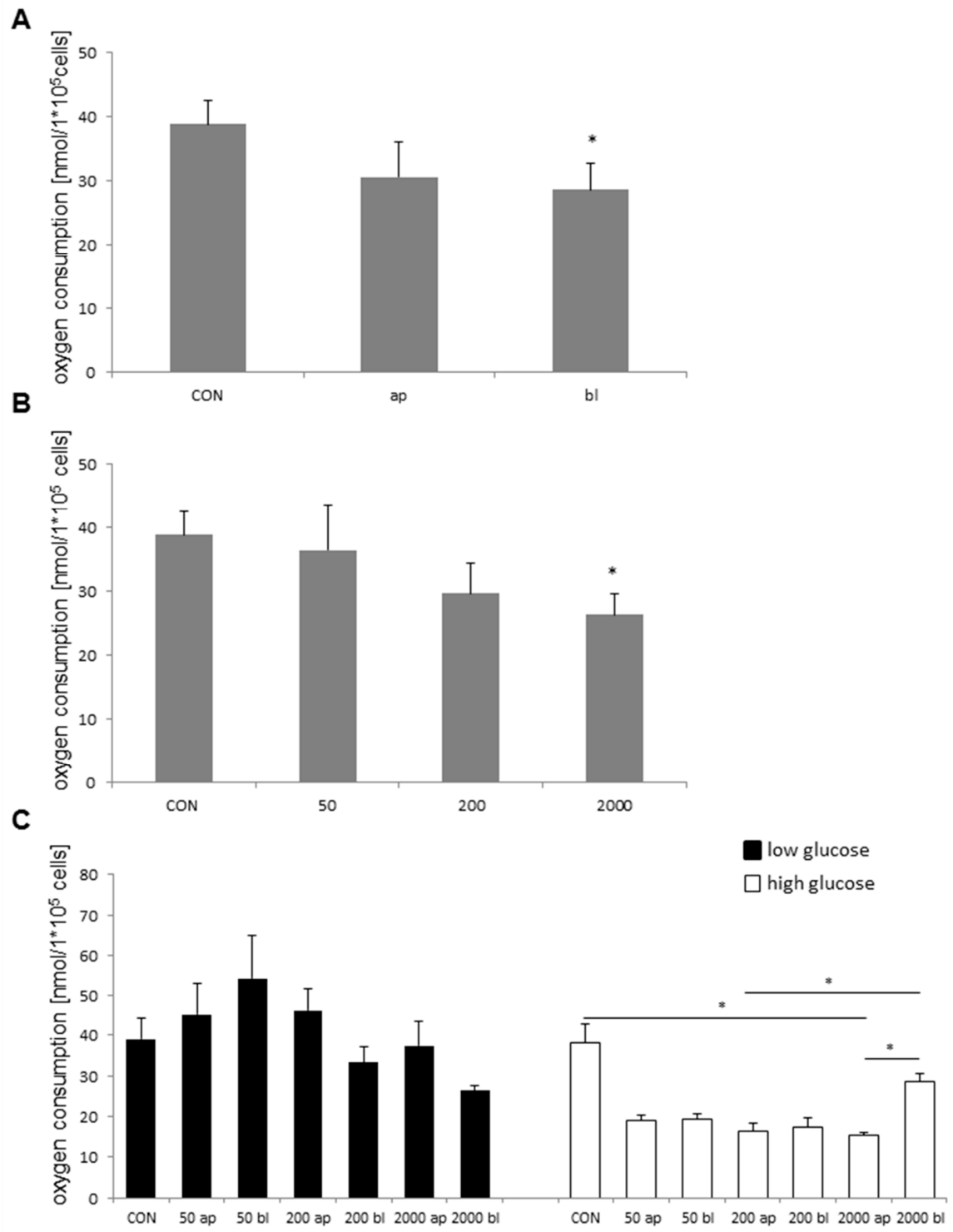

Figure 6. Oxygen consumption $(N=5)$ dependent on DON-application (A), concentration (B), and glucose concentration (C). (A) Apical and basolateral application independent of glucose concentration and DON-concentration resulted in a slight, but not significant decrease in apical application when compared to the control (Kruskal-Wallis Test; $p=0.01$; Mann-Whitney Test; $p=0.003$ ); control: $38.85 \mathrm{nmol} / \mathrm{L} \times 10^{5}$ cells; apical: $30.60 \mathrm{nmol} / \mathrm{L} \times 10^{5}$ cells) and showed a significant decrease in basolateral application $\left(28.68 \mathrm{nmol} / \mathrm{L} \times 10^{5}\right.$ cells). (B) In the next step, the effect of different DON concentrations on oxygen consumption was analyzed. Therefore, all data were summarized and divided into four groups (Kruskal-Wallis Test; $p=0.019$; Mann-Whitney Test; $p=0.006$; CON: $38.85 \mathrm{nmol} / \mathrm{L} \times 10^{5}$ cells; 50: $36.44 \mathrm{nmol} / \mathrm{L} \times 10^{5}$ cells; 200: $29.66 \mathrm{nmol} / \mathrm{L} \times 10^{5}$ cells; 2000: $26.34 \mathrm{nmol} / \mathrm{L} \times 10^{5}$ cells). A significant difference was found between CON vs. 2000. (C) Under low glucose supply, no significant differences were detectable (Kruskal-Wallis; $p=0.089$ ): CON 38.85 $\mathrm{nmol} / \mathrm{L} \times 10^{5}$ cells; 50 ap: $45.42 \mathrm{nmol} / \mathrm{L} \times 10^{5} ; 50 \mathrm{bl}: 54.34 \mathrm{nmol} / \mathrm{L} \times 10^{5} ; 200 \mathrm{ap:} 46.30 \mathrm{nmol} / \mathrm{L}$ $\times 10^{5} ; 200$ bl: $33.24 \mathrm{nmol} / \mathrm{L} \times 10^{5} ; 2000$ ap: $37.34 \mathrm{nmol} / \mathrm{L} \times 10^{5} ; 2000 \mathrm{bl:} 26.37 \mathrm{nmol} / \mathrm{L} \times 10^{5}$ cells . Furthermore, oxygen consumption under different DON concentrations and high glucose supply was analyzed (Welch ANOVA; $p=0.004$ ). A trend of lower oxygen consumption was detected under 50 ap (19.16 nmol $/ \mathrm{L} \times 10^{5}$ cells; $\left.p=0.089\right), 50 \mathrm{bl}\left(19.23 \mathrm{nmol} / \mathrm{L} \times 10^{5} ; p=0.088\right), 200 \mathrm{ap}\left(16.4 \mathrm{nmol} / \mathrm{L} \times 10^{5}\right.$ cells; $p=0.051)$, and $200 \mathrm{bl}\left(17.46 \mathrm{nmol} / \mathrm{L} \times 10^{5}\right.$ cells; $\left.p=0.062\right)$. A significant difference was found between CON vs. 2000 ap (15.22 nmol/L $\times 10^{5}$ cells; $\left.p=0.047\right), 200$ ap vs. $2000 \mathrm{bl}\left(28.47 \mathrm{nmol} / \mathrm{L} \times 10^{5}\right.$ cells; $p=0.035)$, and 2000 ap vs. $2000 \mathrm{bl}(p=0.016)\left(p<0.05^{*}\right)$. 


\subsection{Glucose Consumption and Lactate Production under High Glucose Concentration}

Furthermore, glucose consumption was analyzed in the apical and basolateral supernatants. Overall consumption was averaged and we found a significantly higher glucose consumption in 2000 bl (12.94 mmol/L × $10^{5}$ cells; Welch ANOVA; $p<0.001$; Games Howell; Figure 7A) when compared to all other treatment groups. On the other hand, we detected a significantly lower glucose consumption in 2000 ap when compared to all other groups $\left(5.66 \mathrm{mmol} / \mathrm{L} \times 10^{5}\right.$ cells; $\left.p<0.001\right)$.
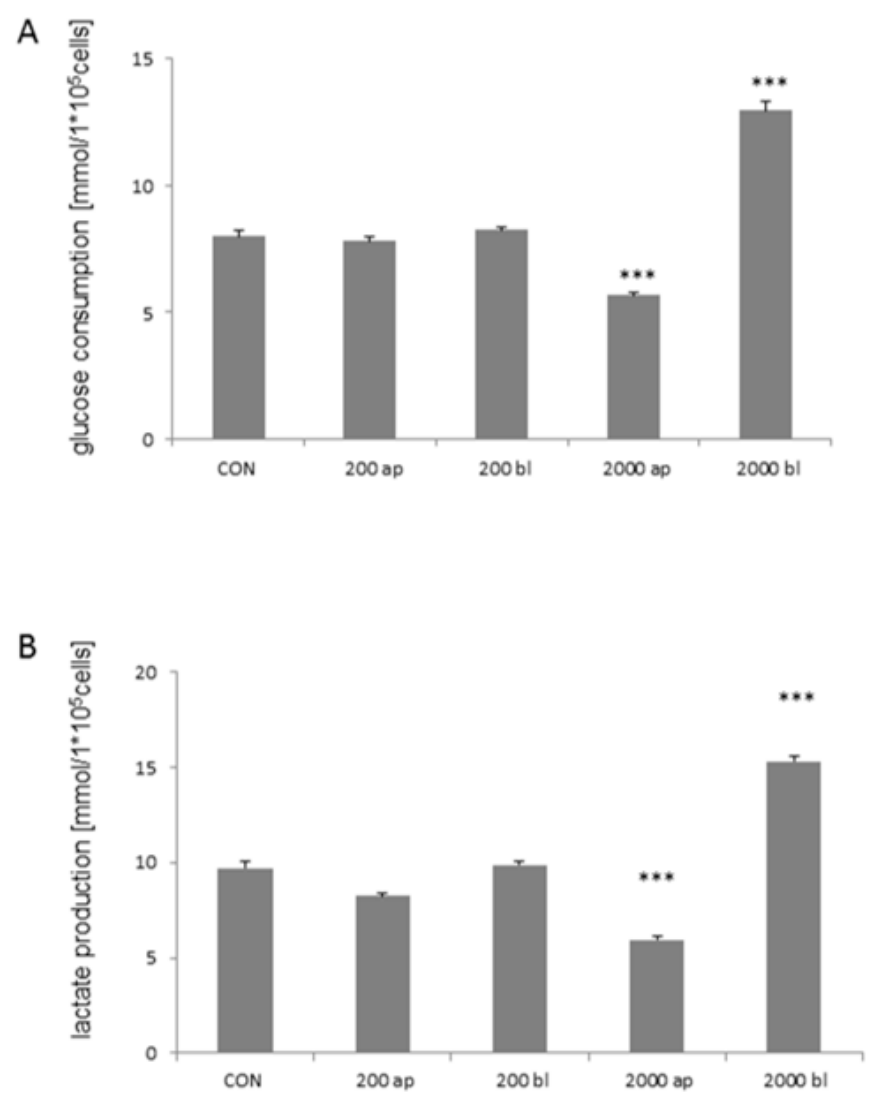

Figure 7. Glucose consumption and lactate production $(N=5)$. (A) Glucose consumption was measured in the apical and basolateral compartments. The overall consumption was measured and analyzed. In the DON treatment groups 2000 ap and $2000 \mathrm{bl}$, significant differences when compared to all other treatment groups could be detected (Welch ANOVA; Games Howell, $p<0.001$ ). (B) Lactate production was analyzed in the apical and basolateral compartments and overall production was calculated $($ ANOVA; F $(4 ; 28)=183.068 ; p<0.001)$. A significantly higher production was found in $2000 \mathrm{bl}(15.32$ $\mathrm{mmol} / \mathrm{L} \times 10^{5}$ cells $)$. A lower production was found in 2000 ap $\left(5.96 \mathrm{mmol} / \mathrm{L} \times 10^{5}\right.$ cells; $\left.p<0.001\right)$. Furthermore, significant differences were detected in all comparisons against each other with the exception of CON vs. 200 bl. $\left(p<0.001^{* * *}\right)$.

In addition, the lactate production of the cells was measured, and we observed similar results as shown in glucose consumption. A significantly higher production was found in $2000 \mathrm{bl}(15.32$ $\mathrm{mmol} / \mathrm{L} \times 10^{5}$ cells; $p<0.001$; Figure 7B) and a lower production in 2000 ap $\left(5.96 \mathrm{mmol} / \mathrm{L} \times 10^{5}\right.$ cells; $p<0.001$ ) when compared to all other treatment groups (ANOVA; F $(4 ; 28)=183.068 ; p<0.001$ ). Furthermore, significant differences were detected in the comparisons of all with each other except for CON vs. 200 bl. In addition, important genes of glucose- and lactate transport were analyzed via qPCR. A significant increase in GLUT1-RNA-level was found in 2000 ap and bl independent of glucose concentration or the used housekeeper (Table 2; $p$ 0.001). A marked up-regulation was also found in all other DON-treatment groups ${ }^{\text {low }}$ when compared to the control. An increased SGLT1-RNA-level was detected in 50 ap and 50 bl under low glucose concentrations, but was decreased in 2000 bl 
$(p<0.001 ; \beta$-actin). Decreasing values were also found with the second housekeeper 18S. Furthermore, MCT1 was analyzed using qPCR. We observed an up-regulation at $50 \mathrm{ap}, 50 \mathrm{bl}$, and $2000 \mathrm{bl}$ (Table 2; $p<0.001, \beta$-actin). A marked, but not significant, increase was also found using $18 \mathrm{~S}$ as the housekeeper.

\subsection{Metabolic Pathway in IPEC-J2}

Figure 8A shows the ATP analyses under different treatments to evaluate the metabolic pathway of IPEC-J2 under high and low glucose conditions. Under high glucose conditions, we detected no significant decrease of ATP in the treatment group without (wo) glucose when compared to the control and FCCP when compared to the control. A significant decrease in the ATP content was observed in the cells that were treated with 2DG in comparison to the control and FCCP (Welch ANOVA; $p<0.001$; Games Howell). In contrast, a significant decrease was found in FCCP and 2DG when compared to the control (ANOVA; F $(3 ; 8)=61.463 ; p<0.001$; Figure 8A) under low glucose conditions.

A
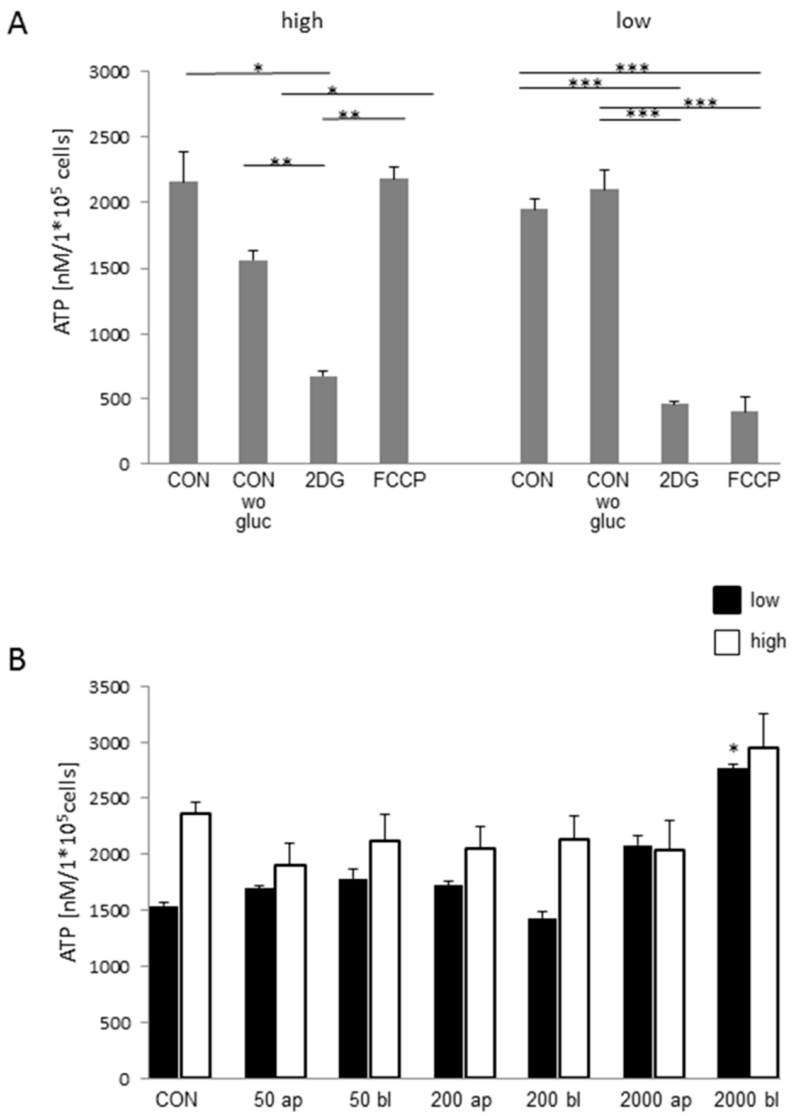

Figure 8. ATP-content $(N=3)$. (A) ATP values for high glucose conditions were analyzed by Welch ANOVA ( $p<0.001$; Games Howell. A significantly lower ATP concentration was found in the treatment group of $2 \mathrm{DG}$ when compared to the control $(p=0.036)$. 2DG $(p=0.0002)$ and FCCP $(p=0.012)$ were significantly different from CON wo gluc. Additionally, FCCP $(p=0.002)$ showed a significantly higher ATP content than 2DG. Under low glucose supply (ANOVA F $(3,8)=61.463 ; p<0.001$ ), 2DG and FCCP showed a significantly lower ATP content when compared to the control. The same result was observed when compared to CON wo glucose. (B) No differences were observed with the focus on ATP concentration under high glucose conditions (Kruskal-Wallis Test; $p=0.653$ ). Furthermore, $2000 \mathrm{bl}$ showed a significantly higher ATP concentration under low glucose supply when compared to all other treatment groups (ANOVA F $(6 ; 14)=11.768 ; p<0.001$; Tukey). Additionally, 200 bl was significantly lower when compared to 2000 ap $(p=0.040)$. In the comparisons of high and low glucose with the appropriate DON-treatment, no differences were detected. $\left(p<0.05^{*} ; p<0.01^{* *} ; p<0.005^{* * *}\right)$. 


\subsection{ATP-Concentration Depends on Glucose-and DON-Concentration}

Under high glucose conditions (Figure 8B), we observed no differences in the comparison of DON-treatment groups to the control (Kruskal-Wallis Test; $p=0.653$ ). In the next step, we analyzed the treatment groups under low glucose supply and found a significantly higher ATP concentration in the $2000 \mathrm{bl}$ DON-treatment group when compared to all other treatment groups (ANOVA F $(6 ; 14)=11.768$; $p<0.001$; Tukey). In the comparisons of high and low glucose with the appropriate DON-treatment, we detected no differences.

Furthermore, COX5B is an important gene of the respiratory chain, which encodes cytochrome C oxidase subunit 5B. Cytochrome $\mathrm{C}$ oxidase is the terminal enzyme of the last step of the respiratory pathway in the mitochondria. A significant upregulation of COX5B was found in 2000 ap independent of glucose concentration (Table 2; $p<0.001 ; \beta$-actin) and was confirmed by 18 S for 2000 ap $^{\text {low }}(p<0.001)$. In 2000 ap ${ }^{\text {high }}$, a marked but not significant increase was found with $18 \mathrm{~S}$.

\subsection{Protein Biosynthesis Rate Depend on DON-Concentration and Application under High Glucose Conditions}

After $72 \mathrm{~h}$ of DON-incubation, we detected increasing synthesis rates starting from $200 \mathrm{ng} / \mathrm{mL}$ and marked higher protein biosynthesis in the $2000 \mathrm{ng} / \mathrm{mL}$ ap and bl treatment groups when compared to the control (Figure 9). In contrast, the protein synthesis rates in groups treated with $50 \mathrm{ng} / \mathrm{mL} \mathrm{DON}$ remained unaffected.

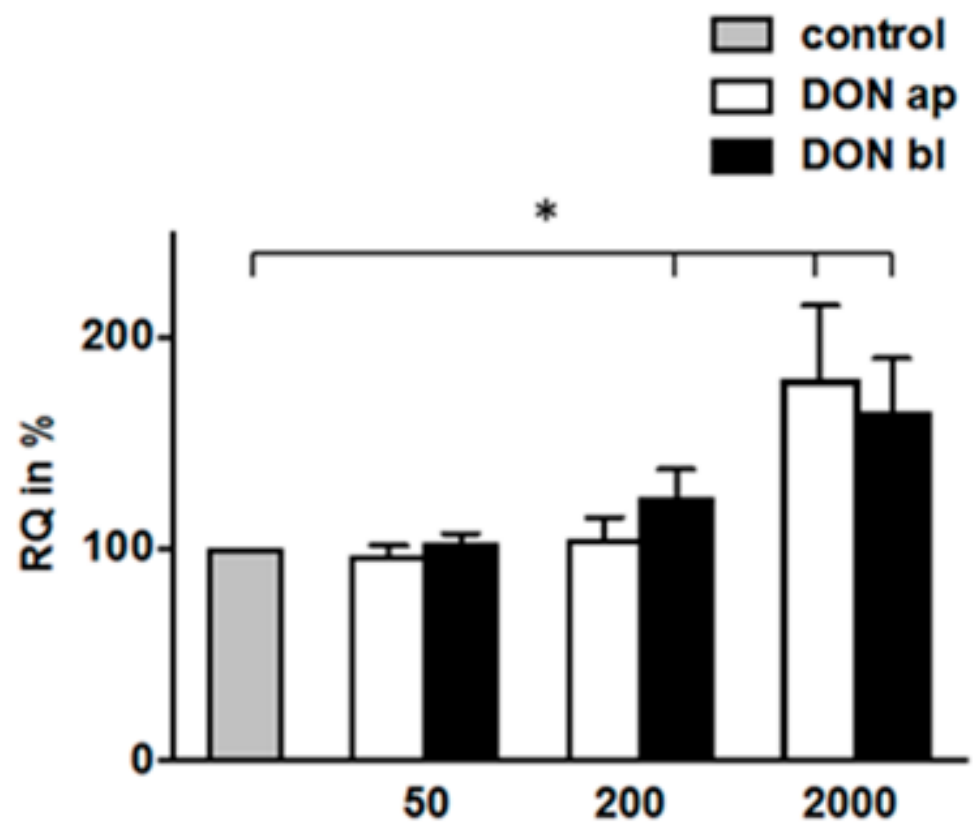

Figure 9. Analyses of protein biosynthesis under high glucose concentration $(N=3)$. After $72 \mathrm{~h}$ of DON treatment, cells were handled as described above. A significantly higher protein synthesis rate (RQ: relative quantification in \%) was found in the $200 \mathrm{ng} / \mathrm{mL} \mathrm{bl}, 2000 \mathrm{ng} / \mathrm{mL}$ ap and bl treatment groups. $\left(p<0.05^{*}\right)$.

\section{Discussion}

In our study, we used two different glucose concentrations to trigger the two different pathways, anaerobic glycolysis and oxidative phosphorylation, in IPEC-J2 to address the question of whether DON had an impact on metabolic function. IPEC-J2 uses glycolysis to a higher proportion as shown by the hexokinase inhibitor 2DG and the uncoupler FCCP [21]. Glycolysis is characterized by the release of lactate into the medium and is detectable as the extracellular acidification rate (ECAR) and lower efficiency of ATP syntheses [21,22]. We also detected a significantly decreased ATP level under high and low glucose conditions in our cells with the use of 2DG, indicating glucose as 
the principle energy source in IPEC-J2 cultures. As a result, the uncoupling of ATP generation by FCCP reduced cellular ATP content only in low glucose conditions. Similar to this is the increased oxygen consumption under low glucose conditions, indicating the optimized usage of glucose derived pyruvate in oxidative phosphorylation. In the microarray analyses of high and low glucose combined with different DON-concentration, we detected different pathways which were significantly regulated: (I) Metabolic pathways, (II) Pathways in cancer, (III) Endocytosis, (IV) PI3K-Akt signaling pathway, and (V) Biosynthesis of antibiotics. Metabolic pathways were the pathway with the highest number of regulated genes. This confirmed our examination model of using high and low glucose to trigger different metabolic pathways in our cells. TXNIP (thioredoxin-interacting protein) was regulated to the highest degree. TXNIP, also known as VDUP1 (vitamin D3 upregulated protein1), is a negative regulator of thioredoxin (TRX) [23], which is an intracellular thiol reductant, and an important regulator of redox balance [24]. Furthermore, TXNIP is an important regulator of cellular glucose and fatty acid metabolism [25], and its transcription is highly induced by glucose [26]. A high expression of the TXNIP protein resulted in reduced glucose uptake and vice versa, a reduced TXNIP protein induced an up-regulation of glucose uptake [27]. We found a down-regulation of TXNIP in our array data in all treatment groups ${ }^{\text {low }}$ when compared to all groups with high glucose. This was confirmed by Western blot analyses. We detected no TXNIP protein in any of the treatment groups ${ }^{\text {low }}$. This makes sense as cells want to up-regulate glucose uptake in a glucose-restricted environment. Furthermore, we found a down-regulation of the TXNIP protein in DON $2000 \mathrm{bl}^{\text {high }}$ when compared to all other treatment groups ${ }^{\text {high, }}$ which agreed with the data of the glucose consumption of the cells. Here, we found a significantly higher value for $2000 \mathrm{bl}$. Another interesting gene is transgelin (TAGLN), which was up-regulated in our examination in the treatment group DON $200 \mathrm{bl}^{\text {low }}$ when compared to DON $200 \mathrm{bl}^{\text {high }}$. TAGLN is a shape-change sensitive actin-binding protein of the calponin family and is found in the cytoskeletal apparatus [28], such as, for example, in the smooth muscle tissue of normal adult vertebrates [29]. Recent studies have provided further evidence that transgelin is also both a tumor suppressor and a variable tumor biomarker, which depends on the tumor type, stage, and experimental model $[30,31]$.

Diesing et al. analyzed the impact of DON under high glucose concentration. They detected TRA1 and CAV2 in response to apical and basolateral DON application (200 and $2000 \mathrm{ng} / \mathrm{mL})$ [9]. TRA1 mRNA was generally down-regulated in the microarray and CAV2 up-regulated. TRA1 is also known as GRP94 or endoplasmin. The promoters of the grp genes constitutively express their gene products, and their promoter activities can be further enhanced in cellular environments of low glucose or oxygen [32]. Awad and Zentek observed an effect of DON, which acts on the intestinal sugar transport by reducing the synthesis of transporter carriers [33]. We also indirectly observed an impact on the glucose transporter as a result of measuring glucose consumption in the apical and basolateral medium, whereas 2000 ap resulted in the lowest and $2000 \mathrm{bl}$ in the highest glucose consumption. This was in agreement with our TXNIP protein data. A down-regulation of TXNIP, which agreed with a higher degree of glucose uptake, was found in $2000 \mathrm{bl}^{\text {high }}$. In $2000 \mathrm{ap}^{\text {high }}$, we found the same results described by Awad and Zentek, where there was a significant decrease in glucose consumption followed by unaffected TXNIP-protein in our analyses. Additionally, we detected decreased lactate production in 2000 bl $^{\text {high }}$, a significantly reduced oxygen consumption, and a significantly up-regulated de novo protein synthesis combined with a marked increase of ATP. Diesing et al. showed in their work, with the focus on an intact intestinal barrier, no or only a weak effect on ZO-1 and Claudin-3, which are two important proteins of the tight junction. They found a stable TEER at $2000 \mathrm{ap}$, but decreased values for $2000 \mathrm{bl}$ [8]. Furthermore, they detected a reduced viability. Our analyses resulted in the same observation of decreased TEER values (Supplementary Materials). Therefore, we assumed that there was an intact barrier in 2000 ap and that the transporter was influenced because of 2000 ap. In contrast, $2000 \mathrm{bl}$ led to a disruption of the intestinal barrier combined with an influence on cell cycle. Diesing et al also found a significantly higher number of BrdU-positive cells in 2000 $\mathrm{bl}$ in comparison to the control at $48 \mathrm{~h}$ and $72 \mathrm{~h}$ of DON-incubation [8]. BrdU is used to label 
proliferating cells. There is a need for glucose in proliferating cells, which cannot be replaced by other metabolizable substances [34]. We hypothesized that a high BrdU-rate, an up-regulation of SLC7A11, higher glucose uptake, high lactate production, up-regulation of de novo protein synthesis, increased ATP content, and possibly also a higher PHB protein content were involved in an activation of proliferation which acted as a survival strategy in 2000 bl ${ }^{\text {high }}$. In contrast, Dänicke et al. could not show any differences in the protein synthesis (fraction synthesis rate; FSR) in the jejunum or jejunal mucosal cells when compared to the control group, but there was a significant reduction in the ileum [13]. SLC7A11 and PHB were the highest up- or down-regulated genes in the comparisons of low glucose. Glutamate/cysteine antiporter solute carrier family 7 member 11 (SLC7A11) was down-regulated in all treatment groups when compared to the control. This was confirmed by qPCR in 2000 ap and $2000 \mathrm{bl}$. SLC7A11 is a $\mathrm{Na}^{+}$independent anionic amino acid transport system, which is highly specific for cysteine and glutamate, that imports extracellular cysteine and exports intracellular glutamate [35]. The uptake of cystine into the cell leads to a rapid reduction to cysteine, the rate limiting amino acid for GSH biosynthesis [36]. GSH in turn protects against the cellular damage caused by free radicals and other reactive oxygen species (ROS) such as superoxide and $\mathrm{H}_{2} \mathrm{O}_{2}$ [37]. With the focus on the SLC7A11 protein, we only found weak differences between the treatment groups but under low glucose conditions, a marked down-regulation under 50 ap, $50 \mathrm{bl}$, and 200 ap when compared to the other treatment groups. It is known that DON induces ROS generation [38]. Increased ROS production leads to oxidative stress that affects endothelial and vascular function, and contributes to vascular disease [39]. An up- or down-regulation of SLC7A11 has a vital influence on the response to oxidative stress induced by DON because SLC7A11 delivers the required cystine for GSH biosynthesis, which protects against oxidative stress. An up-regulation of the SLC7A11 protein under high glucose in the DON-treatment group may be a reply to induced ROS production to enhance GSH production. Differences between low and high glucose with a focus on SLC7A11 expression in general can be induced by the low glucose consumption of the cells and increased ATP demand at the same time. Therefore, cells will increasingly use glutamine as an energy source [40]. Glutamine metabolism results in the generation of key stimulus secretion coupling factors including glutamate and glutathione, which indirectly stimulate ATP production and enhance insulin secretion [39]. Very high concentrations of L-glutamine were used in cell culture (2 up to $10 \mathrm{mM})$, but physiological concentrations were lower $0.7 \mathrm{mM}$ [41]. We supposed that DON comes into action in glutamine metabolism and influences the glutamine uptake, and on the other hand, indirectly on glutamate efflux due to the SLC7A11 transporter of the cells.

Oxygen is necessary for mitochondrial oxidative phosphorylation. Most mammalian cells in culture predominantly use two sources for energy production: glucose and glutamine. These two molecules supply most of the carbon, nitrogen, free energy, and reducing equivalents necessary for cell growth and division [42]. A previous study showed that $90 \%$ of glucose and $60 \%$ of glutamine is converted into lactate or alanine in glioblastoma cells in culture [43]. Both lactate and alanine are secreted from the cell as waste, but more important is the robust generation of $\mathrm{NADH}$, which agrees with the reduction to lactate [44].

One of our questions was how DON modulated the metabolic pathway. A significantly lower glucose consumption was found in DON 2000 ap, but was significantly higher in 2000 bl, which also resulted in a significantly lower lactate production in 2000 ap but was significantly higher in 2000 $\mathrm{ng} / \mathrm{mL}$ bl. In vivo, Bannert et al. showed a lower glucose level at the portal sampling site at 30-45 min in DON-fed pigs (4.59 mg DON $/ \mathrm{kg}$ feed) when compared to the control group, but did not detect any increase or decrease in the lactate levels in pigs in the comparison of CON-fed and DON-fed control groups in their study [45].

The second most significantly regulated gene in all comparisons in our microarray analysis under low glucose supply was PHB. PHB is also known as B-cell-receptor-associated protein 32 (BAP 32). It is an evolutionary conserved protein that is found in eukaryotic organisms [46] and occurs in normal cell membranes; moreover, it is an important protein of mitochondria [47]. We found 
a significantly up-regulated PHB gene at $2000 \mathrm{ng} / \mathrm{mL}$ independent of glucose concentration, but had a differential regulation under high or low glucose consumption. PHB1 and PHB2 are two related proteins that always form a complex in the inner membrane of the mitochondria [48] and regulate cell survival [49], proliferation, and energy metabolism [50]. Under high glucose, we detected an up-regulation and under low glucose supply, there was a down-regulation. Jiang et al. showed that an overexpression of PHB was found in breast cancer tissue and was significantly regulated with tumor recurrence [51]. They also postulated that PHB was one of the major underlying mechanisms of breast cancer development and progression [51]. PHBs have been shown to be associated with complex IV subunits in yeast [52] and with complex I subunits in mammalian cells [42], hinting at the possibility that PHBs might participate in the assembly of mitochondrial electron transport chain (ETC) complexes. Furthermore, Kathiria et al. showed that a deficiency in PHBs led to increased generation of reactive oxygen species (ROS) [48,53], but the underlying mechanism of PHB in mitochondrial ROS production is unknown. With regard to mitochondria, prohibitins also influence the stability of mitochondrial translated proteins $[48,54]$. The assembly of OxPhos complexes is a complicated process and there is a need for both gene products from nuclear and mitochondrial genome. In COX, the subunits are arranged as stoichiometric amounts. Nuclear and mitochondrial encoded subunits need to be provided in a one-to-one ratio [48]. In the metabolic switch between aerobic and anaerobic metabolism, there is a possibility of a temporary imbalance between nuclear and mitochondrial gene products. This occurrence of unassembled, hydrophobic mitochondrial translation products in the inner mitochondrial membrane can cause proton leakage. Prohibitin can also function as a holding complex and to prevent them from misfolding [48].

\section{Conclusions}

Overall, our results showed that DON had an effect on oxygen consumption if it attacks from the basolateral side (Figure 6A). Furthermore, we detected a concentration-dependent impact with the highest effect at 2000 (Figure 6B). Furthermore, we detected differences in glucose consumption and lactate production in $2000 \mathrm{ap}^{\text {high }}$ and $2000 \mathrm{bl}^{\text {high }}$ when compared to the control. If DON attacks from the basolateral side at 2000, we supposed that DON activated the cell cycle (proliferation) as a survival strategy and therefore, lactate production, glucose uptake, and de novo protein synthesis was up-regulated. Contrary results were found if DON operated from the apical side at 2000 because it resulted in significant higher de novo protein production. Important genes such as COX5B, SLC7A11, and PHB were significantly regulated independent of glucose under high DON-concentration. We assumed that DON directly or indirectly affects cell metabolism due to decreased glucose consumption and lactate production in 2000 ap ${ }^{\text {high }}$. This was supported through higher oxygen consumption under $50 \mathrm{ng} / \mathrm{mL}$ DON. Further investigations must to be performed with the focus on de novo protein synthesis, lactate production, and glucose consumption under low glucose conditions.

\section{Materials and Methods}

\subsection{Cell Culture}

Intestinal porcine epithelial cells (a friendly gift from Mariana Roselli, Rome, Italy; IPEC-J2 ACC 701; [55-57]) were regularly tested and found to be free of mycoplasma contamination (Venor GeM Mycoplasma Detection Kit; Minerva Biolabs, Berlin, Germany). DMEM F12 (1:1) (with glutamine: $2.5 \mathrm{mM}$, with D-glucose: $3.16 \mathrm{~g} / \mathrm{L}$ ) supplemented with 5\% fetal bovine serum (FBS), $16 \mathrm{mM}$ 4-(2-hydroxyethyl)-1-piperazineethansulfonic acid (HEPES), 1\% insulin-transferrin-selenium (ITS) (all from PAN-Biotech, Aidenbach, Germany), and $5 \mathrm{ng} / \mathrm{mL}$ epidermal growth factor (EGF, Biochrome, Berlin, Germany) was used as cell culture medium (glucose concentration: $3.16 \mathrm{~g} / \mathrm{L}$; [high]). Medium with low glucose concentration was made with the same supplementations but DMEM/HAMs F12 was mixed with glucose-free DMEM $1 \times$ (with glutamine $4 \mathrm{mM}$, without D-glucose; Gibco, Carlsbad, USA) 
to reach an end concentration of $0.03 \mathrm{~g} / \mathrm{L}$ glucose [low]. In all experiments, cells were seeded with a density of $0.88 \times 10^{5} / \mathrm{cm}^{2}$ on permeable supports (ThinCerts; culture size: $113.1 \mathrm{~mm}^{2}$; pore size: $1 \mu \mathrm{m}$; polyester, Greiner bio-one, Frickenhausen, Germany) in media with high or low glucose concentration (high or low). In the apical compartment, $1 \mathrm{~mL}$ was used and in the basolateral compartment, we used a $2 \mathrm{~mL}$ volume. The medium was changed on days 2, 4, and on day 7, it was supplemented with DON with no further change. Cells grew at $39{ }^{\circ} \mathrm{C}$ in an atmosphere of $5 \% \mathrm{CO}_{2}$ and $100 \%$ relative humidity. The transepithelial electrical resistance was measured on days 7, 8, 9, and 10 of cell culture using a Millicell-TERS-electrode (Millipore, Berlin, Germany; Figure S1).

All of the experiments described below were performed under high glucose and low glucose supply with the exception of the BONCAT analyses (only high glucose).

\subsection{DON-Application}

Deoxynivalenol (DON; D0156; Sigma-Aldrich, Taufkirchen, Germany) was dissolved in absolute ethanol (99.6\%; Roth, Germany; end concentration of ethanol 1\%) to a $0.2 \mathrm{mg} / \mathrm{mL}$ stock solution and a working dilution was prepared in the cell culture medium. Two low DON concentrations of $50 \mathrm{ng} / \mathrm{mL}$ and $200 \mathrm{ng} / \mathrm{mL}$ and a high DON concentration of $2000 \mathrm{ng} / \mathrm{mL}$ were applied, reflecting a non-toxic and a toxic dosage as found in conventional toxicological studies [8]. There were two different application sides: apical or basolateral. This resulted in the following treatment groups: CON, DON $50 \mathrm{ng} / \mathrm{mL}$ ap (50 ap), DON $50 \mathrm{ng} / \mathrm{mL}$ bl (50 bl), DON $200 \mathrm{ng} / \mathrm{mL}$ ap (200 ap), DON $200 \mathrm{ng} / \mathrm{mL}$ bl (200 bl), DON $2000 \mathrm{ng} / \mathrm{mL}$ ap (2000 ap), and DON $2000 \mathrm{ng} / \mathrm{mL}$ bl (2000 bl). On day 7, the medium was exchanged to a medium including different DON-concentrations and cells were incubated for a further $72 \mathrm{~h}$ with DON.

\subsection{RNA Isolation}

After withdrawal of the apical and basolateral medium, cells were covered with TRIzol Reagent (Invitrogen, Germany) as described by the manufacturer's protocol and scraped off the membrane. After adding chloroform to the cell lysate, the supernatant was extracted and RNA was precipitated using isopropanol alcohol. Using 75\% ethanol, the RNA was purified and stored in RNA-free water peqGOLD (PEQLAB, Germany) at $-80{ }^{\circ} \mathrm{C}$ until further processing. Five independent experiments were performed. The RNA was isolated using TRIzol Reagent as per the manufacturer's directions (Sigma-Aldrich, Taufkirchen, Germany). RNA integrity was checked using the 2100 Bioanalyzer platform (Agilent). RNA concentrations were measured on a NanoDrop ND-1000 spectrometer (PEQLAB, Erlangen, Germany). The absence of genomic DNA was checked by PCR amplification of the porcine GAPDH gene. All RNA samples were stored at $-80^{\circ} \mathrm{C}$ until downstream analyses were performed.

\subsection{Microarray}

\subsubsection{Target Preparation and Hybridization}

Regarding comparison I, individual samples covering four treatment groups (DON 200 ap, DON 200 bl, DON 2000 ap, DON 2000 bl) at either low or high glucose level were used for expression analysis ( $\mathrm{n}=3$ per treatment group and glucose level; $\mathrm{n}=24)$. The outcomes of this were four single comparisons: DON 2000 ap ${ }^{\text {high }}$ vs. DON 2000 ap $^{\text {low }}$, DON 2000 bl $^{\text {high }}$ vs. DON 2000 bl $^{\text {low }}$,

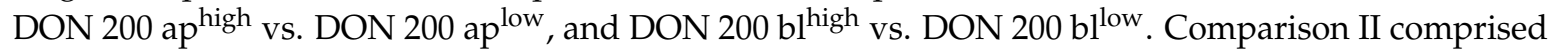
individually treated samples (DON 200 ap, DON 200 bl, DON 2000 ap, DON 2000 bl) and control samples at low glucose level $(n=15)$ (data shown in Figure 3). For the microarray experiments, individual biotin-labeled cRNA samples were hybridized on Affymetrix GeneChip Porcine Genome Arrays according to the manufacturer's directions (Affymetrix, Santa Clara, CA, USA). The raw data were deposited in a MIAME compliant database [58], the National Center for Biotechnology 
Information Gene Expression Omnibus (www.ncbi.nlm.nih.gov/geo; accession numbers: GSE 111184 and GSE 111185).

\subsubsection{Microarray Data Processing}

The microarray covered 24,123 probe sets representing 12,848 genes. The arrays passed the appropriate quality control criteria as previously proposed [59]. The data were GC-RMA normalized (Log2). In order to improve statistical power [60], uninformative data such as internal controls were discarded. Data were filtered by MAS5 (present rate $>50 \%$ per treatment group), standard deviation (comparison I: SD > 0.34; comparison II: SD > 0.19), and mean $(\mathrm{m}>2.5)$ as the corresponding transcripts were unlikely to show altered mRNA abundances. In comparison I, the filtering revealed 9541 probe sets corresponding to 6640 genes (comparison II: 9079 probe sets corresponding to 6328 genes). Relative mRNA differences were analyzed using a linear model including treatment and glucose levels as fixed effects and cell culture passage as a random effect (SAS version 9.4; SAS Institute, Cary, NC, USA). To account for multiple testing, p-values were converted to a set of q-values [61]. The level of significance was set at $p \leq 0.05$ and $q \leq 0.05$, respectively. Lists of altered transcripts were evaluated using Ingenuity Pathway Analysis (IPA, Ingenuity Systems, Redwood City, CA, USA). The significance of association between the dataset and pathway was set at $p \leq 0.05$.

\section{5. $q P C R$}

Quantitative PCR (qPCR) was performed on nine genes identified from the analysis of the gene expression data as potential candidate genes for key mechanisms regulated by DON-treatment. The primers were designed from the same porcine expressed sequence tags (EST) used for the development of the respective probe sets on the Affymetrics GeneChip ${ }^{\circledR}$ Porcine Genome Array (Table 4).

Each $1 \mu \mathrm{g}$ of template RNA was subjected to reverse transcription with First Aid Reverse Transcription Reagents (Fermentas, Germany) essentially as described by the manufacturer with the supplied random hexamer primers in a ThermalCycler TC1 (Biometra, Germany). The resulting cDNA samples were used for qPCR amplification.

Quantitative PCR amplification was performed for all genes under the following conditions on an iCycler (BioRad, München, Germany): $1.5 \mathrm{~min}$ at $95^{\circ} \mathrm{C}, 5 \mathrm{~min}$ at $95^{\circ} \mathrm{C}$ followed by 40 cycles of $30 \mathrm{~s}$ at $95^{\circ} \mathrm{C}$ and $60 \mathrm{~s}$ at an optimal primer annealing temperature (Table 4). Melting curve analysis $\left(50-95^{\circ} \mathrm{C}\right)$ was used for assessing amplification specificity. The reaction volume of $20 \mu \mathrm{L}$ contained $10 \mu \mathrm{L}$ Maxima Mastermix (2×, ThermoFisher [Fermentas], Waltham, MA, USA) with SYBR ${ }^{\circledR}$ Green and Fluorescein as internal standards, $2 \mathrm{pmol} / \mu \mathrm{L}$ of the respective primers $(3 \mu \mathrm{L}$ each), $2 \mu \mathrm{L}$ nuclease free water, and $2 \mu \mathrm{L} \mathrm{cDNA}(60 \mathrm{ng} / \mu \mathrm{L})$.

Analysis of the expression data was done according to the relative standard curve method. A standard curve was derived for each single gene from a serial dilution of the cDNA. The analysis comprised of five independent experiments with each sample in triplicate. The ddCt method [62] was used for the calculation of differences in the gene expression ( ratio $=2^{-\mathrm{ddCt}}$ ). The differences between the DON-treated samples and the untreated control in the relative quantification (rq) values were normalized to the individual expression of the two housekeeping genes $\beta$-actin and 18S. 
Table 4. Used primer pairs.

\begin{tabular}{ccccc}
\hline Gene & Left $\left(\mathbf{5}^{\prime} \mathbf{-} \mathbf{3}^{\prime}\right)$ & Right $\left(\mathbf{5}^{\prime}-\mathbf{3}^{\prime}\right)$ & Product Size & Temperature $\left[{ }^{\circ} \mathbf{C}\right]$ \\
\hline $18 S$ & GCAATTATTCCCCATGAACG & GGCCTCACTAAACCATCCAA & 123 \\
beta-actin & GATGAGATTGGCATGGCTTT & CACCTTCACCGTTCCAGTTT & 122 \\
TXNIP & AGCAGCCAAGAGAACAGAGA & TCCACGGACACAATACCCA & 118 \\
PHB & TGA AAA CTC TGC CCC TGT GA & TCT GCA GGA CTC ACA TCT CG & 119 & 56.5 \\
SLC7A11 & TAA ATT TGG GTG CAA TGT GAT GT & TTG AAG CAA CTA GAA GCA TGA CA & 99 & 57.2 \\
MCT1 & TCCATCATGTTGGCTGTCAT & GAAGGAAGCTGCAATCAAGC & 129 & 57.3 \\
COX5B & GGAGAGGGAGGTCATGATGG & CCACTATCCGCTTGTTGGTG & 128 \\
SGLT-1 & AAGCTGGTCATGGAGCTGAT & AGACGTCCATGGTGAAGAGG & 127 \\
GLUT1 & GAGCCCTGCCTAGACACTTG & CCACCTCTTGGGGTAGAAGA & 58.9 & 59.4 \\
\hline
\end{tabular}




\subsection{Western Blot}

For the protein analysis, IPEC-J2 was cultured in ThinCerts ${ }^{\mathrm{TM}}$ with a $15 \mathrm{~mm}$ diameter. At least three independent experiments were performed. Medium was withdrawn, cells were washed in phosphate buffered saline (PBS), and sodium dodecyl sulfate (SDS) loading buffer was added (10 mL containing $600 \mu \mathrm{L} 1 \mathrm{M}$ Tris base pH 6.8, $1000 \mu \mathrm{L}$ glycerol, $2000 \mu \mathrm{L}$ 10\%-SDS, $500 \mu \mathrm{L}$ 0.1\%-bromophenol blue, $500 \mu \mathrm{L} \beta$-mercaptoethanol; $5.4 \mathrm{~mL}$ aqua dest). For protein denaturation, the lysate was heated up to $95{ }^{\circ} \mathrm{C}$ for $5 \mathrm{~min}$. Quantification of protein content was performed using Molecular probes ${ }^{\circledR}$ Qubit Protein Assay Kit and Qubit ${ }^{\circledR}$ 2.0 Fluorometer (both Thermo Fisher (Invitrogen], Waltham, MA, USA) in accordance to the manufacturer's protocols.

For Western blot, $40 \mu \mathrm{g}$ of protein sample as well as Page Ruler ${ }^{\mathrm{TM}}$ prestained protein ladder (SM0671; Thermo Fisher [Fermentas], Waltham, MA, USA) were placed on SDS polyacrylamide gel. After electrophoresis, samples were transferred to $0.45 \mu \mathrm{m}$ PVDF membrane by semi-dry electroblotting using TRANS-BLOT ${ }^{\circledR}$ SD Semi Dry Transfer Cell (Bio-Rad, Munich, Germany). Protein detection was performed employing the BM Chemiluminescence Western Blotting Kit (Mouse/Rabbit) by following the manufacturer's instructions (Roche, Basel, Switzerland). Primary antibodies were utilized to identify specific proteins: rabbit anti-PHB (1:2000, o.n. $4{ }^{\circ} \mathrm{C}$; Abcam, Cambridge, UK), rabbit anti-SLC7A11 (1:2000; o.n. $4{ }^{\circ} \mathrm{C}$, antibody verify, Las Vegas, NV, USA), rabbit anti-TXNIP (1:2000; o.n. $4{ }^{\circ} \mathrm{C}$; abcam, Cambridge, UK), and mouse anti- $\beta$-actin 1:40000 (Sigma-Aldrich, Munich, Germany). Blots were visualized by Multilmage ${ }^{\mathrm{TM}}$ Light Cabinet (Alpha Innotech, Kasendorf, Germany).

\subsection{Oxygen Measurement}

The oxygen uptake was measured with a Microx TX3 (Presens, Regensburg, Germany). The sensor was calibrated as per the manufacturer's instructions (manual; 2-point calibration). The oxygen sensor was placed directly over the cells/membrane, which were stored in an incubator at $39{ }^{\circ} \mathrm{C}\left(5 \% \mathrm{CO}_{2}\right.$ and $100 \%$ humidity). After $30 \mathrm{~min}$ of equilibration, the measurement was started. The oxygen content in the cell medium (apical) was measured and averaged over $10 \mathrm{~min}$ at intervals of $30 \mathrm{~s}$. Inserts with medium but without cells were used as blank (the basic content of oxygen directly over the membrane). The oxygen uptake was given due to the difference between both values (blank - sample value $=$ oxygen uptake).

At the end of the experiment, cells were fixed with ethanol $\left(96 \% ; 30 \mathrm{~min} ; 4^{\circ} \mathrm{C}\right)$ and acetone $(30 \mathrm{~s})$. In the next step, cells were stained with 4',6-Diamidin-2-phenylindol (5 min; 1:10 in 0.1 M phosphate buffer (PB). Next, cells were washed with 0.1 M PB and mounted with Mowiol. Membranes were used for cell counting. Therefore, five randomized pictures were taken from each membrane.

\subsection{Lactate and Glucose Measurement}

In order to measure the oxygen content within the cell culture medium, IPEC-J2 was grown on ThinCerts ${ }^{\mathrm{TM}}$, but the medium was unaltered during the final $72 \mathrm{~h}$ of cultivation and treatment. After the termination of cell culture, the medium was fully withdrawn from the cells and transferred into separate tubes according to the compartment distinguishing between the upper (apical) and lower (basolateral) compartments. All samples were stored on ice until measurement. Cell-free cell culture medium was used as a blank. Glucose and lactate concentrations were determined immediately using Cobas C 501 (Roche, Basel, Switzerland) as well as the reagents of test systems GLUC2 and LACT2 (Roche, Basel, Switzerland), respectively. The differences in glucose and lactate concentration between the blank and samples were considered as glucose consumption and lactate production. Glucose measurements of DON-treated cells under low glucose conditions resulted in values which are located below the detection limit of $0.11 \mathrm{mmol} / \mathrm{L}$. Therefore, analyses of experiments with low glucose were not shown in the results. 


\subsection{ATP Measurement}

Cells were seeded on 12-well-ThinCerts for 10 days. On day 7, cells were treated apical or basolateral with different DON concentrations $50 \mathrm{ng} / \mathrm{mL}, 200 \mathrm{ng} / \mathrm{mL}$, and $2000 \mathrm{ng} / \mathrm{mL}$. On day 9 , control cells were treated with or without carbonylcyanid-4-trifluormethoxyphenylhydrazon (FCCP, $5 \mu \mathrm{M}$ in DMSO, Sigma-Aldrich, Hamburg, Germany), 2-Deoxy-glucose (2DG; $5 \mathrm{mM}$ in glucose-free medium) or with medium without glucose for $24 \mathrm{~h}$. On day 10, media were removed and a boiling hot puffer (300 $\mu \mathrm{L}$ /well; 100 mM TRIS; 4 mM EDTA; pH 7.75, Roth, Karlsruhe, Germany) was added to the cells. In the next step, cells were scraped off the membrane with a cell scraper. The cell suspension was transferred into a tube, incubated for $2 \mathrm{~min}$ at $100^{\circ} \mathrm{C}$, centrifuged at $1000 \times g$ for $60 \mathrm{~s}$. Supernatants were pipetted into a 96-well-microplate $(50 \mu \mathrm{L} /$ well; triplicates; Greiner bio-one; Frickenhausen, Germany). Samples kept on ice until measurement. An ATP-standard curve was prepared following the manufacturer's instructions (five readings within 5 min; $25^{\circ} \mathrm{C}$; ATP Bioluminescence Assay Kit CLS II; Roche, Basel, Switzerland).

\subsection{Analyses of the Protein Biosynthesis}

\subsubsection{Metabolic Labeling and Treatment of IPEC-J2}

Labeling experiments were performed according to Müller et al. [63] in methionine-free DMEM medium supplemented with either $4 \mathrm{mM}$ methionine (Met) or $4 \mathrm{mM}$ azidohomoalanine (AHA). At day 7, cells were incubated with different DON-concentrations for $48 \mathrm{~h}$ with DMEM/HAMF12 (see above).

Subsequently, media were exchanged to Met-free media and cells were pre-incubated for $30 \mathrm{~min}$. Afterwards, the Met-free media were replaced by the above described media containing AHA or Met as a control.

After $24 \mathrm{~h}$ cells were harvested with trypsin $\left(10 \mathrm{~min} ; 39^{\circ} \mathrm{C}\right)$, centrifuged $(10 \mathrm{~min} ; 350 \times \mathrm{g})$, and washed with PBS. Subsequently, cell pellets were washed twice with PBS (pH 7.8) and frozen at $-80^{\circ} \mathrm{C}$.

\subsubsection{Bioorthogonal Non-Canonical Amino Acid Tagging (BONCAT)}

Tagging of AHA labeled proteins was performed as essentially described in Dieterich et al. and Landgraf et al. [64,65]. Briefly, cell pellets were lysed for 5 min at $95{ }^{\circ} \mathrm{C}$ in $300 \mu \mathrm{L} 1 \times$ PBS, $\mathrm{pH} 7.8$, containing $0.2 \%$ Triton X100, $0.1 \%$ SDS, $1 \times$ cOmplete $^{\mathrm{TM}}$ EDTA-free protease inhibitor cocktail (Roche, Basel, Switzerland), and $250 \mathrm{U} / \mathrm{mL}$ Benzonase ${ }^{\circledR}$ nuclease. The resulting protein extracts were centrifuged for $5 \mathrm{~min}$ at $14,000 \times \mathrm{g}$ at $4{ }^{\circ} \mathrm{C}$, and the supernatant transferred into fresh $1.5 \mathrm{~mL}$ Eppendorf tubes. For click-chemistry, samples were supplemented with $0.2 \mathrm{mM}$ Triazole ligand (tris[(1-benzyl-1H-1,2,3-triazol-4-yl) methyl] amine (TBTA), $25 \mu \mathrm{M}$ biotin- $\mathrm{PEO}_{3}$-alkyne-tag, and $0.2 \mathrm{mg} / \mathrm{mL}$ copper(I)bromide-suspension (Acros/Thermo Fisher Scientific, Munich, Germany). After the addition of each reagent, samples were thoroughly vortexed for $15 \mathrm{~s}$. Subsequently, samples were incubated under continuous agitation at RT. After $2 \mathrm{~h}$ reaction time, precipitates were removed by centrifugation for $5 \mathrm{~min}$ at $3000 \times \mathrm{g}, 4^{\circ} \mathrm{C}$, and the remaining protein extracts were further processed for quantification, SDS-PAGE, and Western blot.

\subsubsection{Western Blot Experiments and Quantitative Analysis}

For SDS-PAGE and Western blot analysis, protein fractions were solubilized with $4 \times$ SDS sample buffer ( $250 \mathrm{mM}$ Tris- $\mathrm{HCl}$, pH 6.8, 1\% SDS, 40\% glycerol, 20\% $\beta$-mercaptoethanol, $0.004 \%$ bromophenol blue), boiled for $5 \mathrm{~min}\left(95^{\circ} \mathrm{C}\right)$ and separated on 5-20\% SDS-polyacrylamide gradient gels, subsequently followed by transfer onto nitro cellulose membranes. After blotting, membranes were blocked with blocking solution ( $5 \%$ dry milk, $0.1 \%$ Tween 20 in $1 \times$ TBS) for $1 \mathrm{~h}$ at RT with gentle agitation. Incubation with primary antibodies (anti-biotin, 1:10,000) was done overnight at $4{ }^{\circ} \mathrm{C}$ in blocking solution. After intensive washing, blots were incubated for $90 \mathrm{~min}$ at room temperature with HRP-conjugated 
secondary antibodies $(1: 10,000)$ in blocking solution and finally developed with ECL reagent (Thermo Fisher Scientific, Waltham, MA, USA) using the Odyssey ${ }^{\circledR}$ Fc luminescence detector (LI-COR).

For normalization, identical samples were separated by SDS-PAGE and stained for $1 \mathrm{~h}$ with $0.05 \%$ Coomassie brilliant blue dissolved in 50\% methanol and 10\% acetic acid, followed by destaining using a solution consisting of 5\% methanol and $7 \%$ acetic acid. Determination and quantification of the Western blot signals and Coomassie-stained gels was done using the Image Studio Lite version 5.0 software from LI-COR.

\subsubsection{Statistical Analysis}

Data were tested for normal distribution with the Kolmogorov-Smirnov test with SPSS 24. In the event of a normal distribution, a Levene test was used to test for variance homogeneity. Furthermore, an ANOVA (Levene Test negative; Tukey Test) or a Welch ANOVA (Levene Test positive; Games-Howell) was used for further analyses. In the case of a significant result (no normal distribution), a Kruskal-Wallis test was used to check for differences between groups. In the case of a significant result, a Mann-Whitney test was performed and p-values were corrected (alpha correction). qPCR data for TXNIP based on pairwise comparisons of high and low glucose (Figure 2B) were also checked for normal distribution with the Kolmogorov-Smirnov test (delta-CT values). In the event of normal distribution, a t-test was performed to display significant changes. A Mann-Whitney test was used in the event of no normal distribution. The same procedure was performed for SLC7A11 and PHB.

Supplementary Materials: The following are available online at http:/ /www.mdpi.com/2072-6651/10/11/464/s1, Figure S1: TEER measurements under high (A) and low (B) glucose conditions.

Author Contributions: Conceptualization, C.N.; Formal analysis, C.N., P.L., S.K., M.O. and K.W.; Methodology, C.N., P.L., M.O., B.I., D.C.D. and K.W.; Resources, P.L., M.O., B.I., D.C.D. and K.W.; Validation, C.N., P.L., S.K., M.O. and K.W.; Writing—original draft, C.N., P.L. and M.O.; Writing—review and editing, C.N., P.L., S.K., M.O., B.I., D.C.D., K.W., S.D. and H.-J.R.

Funding: This research received no external funding.

Acknowledgments: The authors are indebted to Anke Schmidt, Sandra Vorwerk, Romina Wolter and Evelyn Dankert for their technical assistance. Furthermore, we have to thank Lux (Institute for Biometry and Medical Informatics) for their support in statistical analysis.

Conflicts of Interest: The authors declare no conflict of interest.

$\begin{array}{ll}\text { Abbreviations } \\ \text { AcCoA } & \text { acetyl coenzyme A } \\ \text { AHA } & \text { azidohomoalanine } \\ \text { ap } & \text { apical } \\ \text { ATP } & \text { adenosinetriphosphate } \\ \text { bl } & \text { basolateral } \\ \text { BONCAT } & \text { bioorthogonal non-canonical amino acid tagging } \\ \text { CAV2 } & \text { caveolin-2 } \\ \text { COX5B } & \text { cytochrome C oxidase subunit 5B } \\ \text { CYP26B1 } & \begin{array}{l}\text { cytochrome P450 26B1 } \\ \text { 2DG }\end{array} \text { 2-deoxy-glucose } \\ \text { DON } & \text { deoxynivalenol } \\ \text { EGF } & \text { epidermal growth factor } \\ \text { EST } & \begin{array}{l}\text { expressed sequence tags } \\ \text { electron transport chain }\end{array} \\ \text { ETC } & \text { flavine adenine dinucleotide } \\ \text { FADH } & \text { fetal bovine serum } \\ \text { FBS } & \text { carbonylcyanid-4-trifluormethoxyphenylhydrazon } \\ \text { FCCP } & \text { glycerinaldehyd-3-phosphate dehydrogenase } \\ \text { GAPDH } & \text { glutathione } \\ \text { GSH } & \end{array}$




$\begin{array}{ll}\text { HEPES } & \text { 4-(2-hydroxyethyl)-1-piperazine ethanesulfonic acid } \\ \text { IPEC-J2 } & \text { intestinal porcine epithelial cells } \\ \text { ITS } & \text { insulin-transferrin-selenium } \\ \text { Met } & \text { methionine } \\ \text { MEST } & \text { mesoderm-specific transcript homologues protein } \\ \text { NADPH } & \text { nicotinamide adenine dinucleotide phosphate } \\ \text { OxPhos } & \text { oxidative phosphorylation } \\ \text { PB } & \text { phosphate buffer } \\ \text { PBS } & \text { phosphate buffered saline } \\ \text { PHB } & \text { prohibitin } \\ \text { PKR } & \text { protein kinase R } \\ \text { PVDF } & \text { polyvinylidenfluoride } \\ \text { ROS } & \text { reactive oxygen species } \\ \text { RQ } & \text { relative quantification } \\ \text { SDS } & \text { sodium dodecyl sulfate } \\ \text { SLC6A19 } & \text { system B(0) neutral amino acid transporter AT1 } \\ \text { SLC7A11 } & \text { solute carrier family 7 member 11 } \\ \text { TAGLN } & \text { transgelin } \\ \text { TBTA } & \text { tris[(1-benzyl-1H-1,2,3-triazol-4-yl)methyl]amine } \\ \text { TRA1 } & \text { tumor rejection antigen 1 (A GRP94, HSP90) } \\ \text { TRIS } & \text { tris(hydroxymethyl)aminomethane } \\ \text { VDUP1 } & \text { vitamin D3 upregulated protein1 } \\ & \end{array}$

\section{References}

1. Dalli, J. The Rapid Alert System for Food and Feed; Office for Official Publications of the European Communities: Luxembourg, 2010; ISBN 978-92-79-19765-9.

2. Schothorst, R.C.; Jekel, A.A. Determination of trichothecenes in beer by capillary gas chromatography with flame ionisation detection. Food Chem. 2003, 82, 475-479. [CrossRef]

3. Rotter, B.; Prelusky, D.; Pestka, J. Toxicology of deoxynivalenol (vomitoxin). J. Toxicol. Environ. Health 1996, 48, 1-34. [CrossRef] [PubMed]

4. Maresca, M.; Mahfoud, R.; Garmy, N.; Fantini, J. The mycotoxin deoxynivalenol affects nutrient absorption in human intestinal epithelial cells. J. Nutr. 2002, 132, 2723-2731. [CrossRef] [PubMed]

5. Wu, L.; Liao, P.; He, L.; Ren, W.; Yin, J.; Duan, J.; Li, T. Growth performance serum biological profile, jejunal morphology, and the expression of nutrient transporter genes in deoxynivalenol-challenged growing pigs. BMC Vet. Res. 2015, 11, 144. [CrossRef] [PubMed]

6. Dänicke, S.; Kersten, S.; Valenta, H.; Breves, G. Inactivation of deoxinevalenol-contaminated cereal grains with sodium metabisulfite: A review of procedures and toxical aspects. Mycotoxin Res. 2012, 28, 199-218. [CrossRef] [PubMed]

7. Zerull, K.; Breves, G.; Schröder, B.; Goyarts, T.; Dänicke, S. The influence of the mycotoxin deoxynivalenol on the jejunal glucose transport in pigs. Mycotoxin Res. 2005, 21, 251-257. [CrossRef] [PubMed]

8. Diesing, A.K.; Nossol, C.; Dänicke, S.; Walk, N.; Post, A.; Kahlert, S.; Rothkötter, H.-J.; Kluess, J. Vulnerability of polarized Intestinal porcine epithelial cells to mycotoxin Deoxynivalenol depends on the route of Application. PLoS ONE 2011, 6, e17472. [CrossRef] [PubMed]

9. Diesing, A.K.; Nossol, C.; Ponsuksili, S.; Wimmers, K.; Kluess, J.; Walk, N.; Post, A.; Rothkötter, H.-J.; Kahlert, S. Gene regulation of intestinal porcine epithelial cells IPEC-J2 is dependent on the site of Deoxynivalenol toxicology action. PLoS ONE 2012, 7, e34136. [CrossRef] [PubMed]

10. Pestka, J.J. Deoxynivalenol-induced proinflammatory gene expression: Mechanisms and pathological sequelae. Toxins 2010, 2, 1300-1317. [CrossRef] [PubMed]

11. Sergent, T.; Parys, M.; Garsou, S.; Pussemier, L.; Schneider, Y.J.; Larondelle, Y. Deoxynivalenol transport across human intestinal caco-2 cells and its effects on cellular metabolism at realistic intestinal concentrations. Toxicol. Lett. 2006, 164, 167-176. [CrossRef] [PubMed]

12. Feinberg, B.; McLaughlin, C.S. Biochemical mechanism of action of trichothecene mycotoxins. In Trichothecene Mycotoxicosis: Pathophysiological Effects; Beasley, V.R., Ed.; CRC Press: Boca Raton, FL, USA, 1989; pp. $27-35$. 
13. Dänicke, S.; Goyarts, T.; Döll, S.; Grove, N.; Spolders, M.; Flachowski, G. Effects of the Fusaium toxin deoxynivalenol on tissue protein synthesis in pig. Toxicol. Lett. 2006, 165, 297-311. [CrossRef] [PubMed]

14. Zhou, H.R.; Lau, A.L.; Pestka, J.J. Role of double-stranded RNA-activated protein kinase R (PKR) in deoxynivalenol-induced ribotoxic stress response. Toxicol. Sci. 2003, 74, 335-344. [CrossRef] [PubMed]

15. Krishnaswamy, R.; Devaraj, S.N.; Padma, V.V. Lutein protects HT-29 cells against deoxynivalenol-induced oxidative stress and apoptosis: Prevention of NF- $\kappa B$ nuclear localization and down regulation of NF- $\kappa B$ and cyclo-oxygenase-2 expression. Free Radic. Biol. Med. 2010, 49, 50-60. [CrossRef] [PubMed]

16. Chaudhary, M.; Rao, P.V. Brain oxidative stress after dermal and subcutaneous exposure of T-2 toxin in mice. Food. Chem. Toxicol. 2010, 48, 3436-3442. [CrossRef] [PubMed]

17. Ott, M.; Gogvadze, V.; Orrenius, S.; Zhivotosky, B. Mitochondria, oxidative stress and cell death. Apoptosis 2007, 12, 913-922. [CrossRef] [PubMed]

18. Nossol, C.; Barta-Böszörmènyi, A.; Kahlert, S.; Zuschratter, W.; Faber-Zuschratter, H.; Reinhardt, N.; Ponsuksili, S.; Wimmers, K.; Diesing, A.K.; Rothkötter, H.-J. Comparing two intestinal porcine epithelial cell lines (IPECs): Morphological differentiation, function and metabolism. PLoS ONE 2015, 10, e0132323. [CrossRef] [PubMed]

19. Nossol, C.; Diesing, A.K.; Kahlert, S.; Kersten, S.; Kluess, J.; Ponsuksili, S.; Hartig, R.; Wimmers, K.; Dänicke, S.; Rothköther, H.-J. Deoxynivalenol affects the composition of the basement membrane proteins and influences en route the migration of $\mathrm{CD}_{1} 6^{+}$cells into the intestinal epithelium. Mycotoxin Res. 2013, 29, 245-254. [CrossRef] [PubMed]

20. Klasvogt, S.; Zuschratter, W.; Schmidt, A.; Kröber, A.; Vorwerk, S.; Wolter, R.; Isermann, B.; Wimmers, K.; Rothkötter, H.-J.; Nossol, C. Air-liquid interface enhances oxidative phosphorylation in intestinal epithelial cell line IPEC-J2. Cell Death Discov. 2017, 3, 17001. [CrossRef] [PubMed]

21. Penny, H.L.; Siew, J.L.; Adriani, G.; Yeao, W.H.; Ee, P.S.; Luis, B.S.; Lee, B.; Lee, T.; Mak, S.Y.; Ho, Y.S.; et al. Warburg metabolism in tumor-conditioned macrophages promotes metastasis in human pancreatic ductal adenocarcinoma. Oncoimmunology 2016, 5, e1191731. [CrossRef] [PubMed]

22. Reyes, R.; Wani, N.A.; Ghoshal, K.; Jacob, S.T.; Motiwala, T. Sorafenib and 2-Deoxyglucose synergistically inhibit proliferation of both Sorafenib sensitive and resistant HCC cells by inhibiting ATP production. Gene Expr. 2017, 17, 129-140. [CrossRef] [PubMed]

23. Nishiyama, A.; Matsui, M.; Iwata, S.; Hirota, K.; Masutani, H.; Nakamura, H.; Takagi, Y.; Sono, H.; Gon, Y.; Yodoi, J. Identification of thioredoxin-binding protein-1/vitamin D3) up-regulated protein 1 as a negative regulator of thioredoxin function and expression. J. Biol. Chem. 1999, 274, 21645-21650. [CrossRef] [PubMed]

24. Yodoi, J.; Nakamura, H.; Masutani, H. Redox regulation of stress signals: Possible roles of dendritic stellate TRX producer cells (DST cell types). Biol. Chem. 2002, 383, 585-590. [CrossRef] [PubMed]

25. Hui, T.Y.; Sheth, S.S.; Diffley, J.M.; Potter, D.W.; Lusis, A.J.; Attie, A.D.; Davis, R.A. Mice lacking thioredoxin-interacting protein provide evidence linking cellular redox state to appropriate response to nutritional signals. J. Biol. Chem. 2004, 279, 24387-24393. [CrossRef] [PubMed]

26. Chal-Molstad, H.; Saxena, G.; Chen, J.; Shalev, A. Glucose-stimulated expression of Txnip is mediated by carbohydrate response element-binding protein, p300, and histone $\mathrm{H} 4$ acetylation in pancreatic beta cells. J. Biol. Chem. 2009, 284, 16898-16905. [CrossRef] [PubMed]

27. Pradelli, L.A.; Villa, E.; Zunino, E.; Marchetti, B.; Ricci, J.E. Glucose metabolism is inhibited by caspases upon the induction of apoptosis. Cell Death Dis. 2014, 5, e1460. [CrossRef] [PubMed]

28. Assinder, S.J.; Stanton, J.A.; Prasad, P.D. Transgelin: An actin-binding protein and tumour suppressor. Int. J. Biochem. Cell Biol. 2009, 41, 482-486. [CrossRef] [PubMed]

29. Lees-Miller, J.P.; Heeley, D.H.; Smillie, L.B. An abundant and novel protein of $22 \mathrm{kDa}$ (SM22) is widely distributed in smooth muscles: Purification from bovine aorta. Biochem. J. 1987, 244, 705-709. [CrossRef] [PubMed]

30. Yang, Z.; Chang, Y.J.; Miyamoto, H.; Ni, J.; Niu, Y.; Chen, Z.; Chen, Y.L.; Yao, J.L.; di Sant Agnese, P.A.; Chang, C. Transgelin functions as a suppressor via inhibition of ARA54-enhanced androgen receptor transactivation and prostate cancer cell growth. Mol. Endocrinol. 2007, 21, 343-358. [CrossRef] [PubMed]

31. Huang, Q.; Huang, Q.; Chen, W.; Wang, L.; Lin, W.; Lin, J.; Lin, X. Identification of transgelin as a potential novel biomarker for gastric adenocarcinoma based on proteomics technology. J. Cancer Res. Clin. Oncol. 2008, 134, 1219-1227. [CrossRef] [PubMed] 
32. Little, E.; Ramakrishnan, M.; Roy, B.; Gazit, G.; Lee, A.S. The glucose-regulated proteins (GRP78 and GRP94): Functions, gene regulation, and application. Crit. Rev. Eukaryot. Gene Expr. 1994, 4, 1-18. [CrossRef] [PubMed]

33. Awad, W.A.; Vahjen, W.; Aschenbach, J.R.; Zentek, J. A diet naturally contaminated with the Fusarium mycotoxin deoxynivalenol (DON) down regulates gene expression of glucose transporters in the intestine of broiler chickens. Livest. Sci. 2011, 140, 72-79. [CrossRef]

34. Greiner, E.F.; Guppy, M.; Brand, K. Glucose is essential for proliferation and the glycolytic enzyme induction that provokes a transition to glycolytic energy production. J. Biol. Chem. 1994, 269, 31484-31490. [PubMed]

35. Sato, H.; Tamba, M.; Kuriyama-Matsumura, K.; Okuno, S.; Bannai, S. Molecular cloning and expression of human xCT, the light chain of amino acid transport system xc. Antioxid. Redox Signal. 2000, 2, 665-671. [CrossRef] [PubMed]

36. Gatti, L.; Zunino, F. Overview of tumor cell chemoresistance mechanisms. Methods Mol. Med. 2005, 111, 127-148. [PubMed]

37. Wu, G.; Fang, Y.Z.; Yang, S.; Lupton, J.R.; Turner, N.D. Glutathione metabolism and its implications for health. J. Nutr. 2004, 134, 489-492. [CrossRef] [PubMed]

38. Ji, G.E.; Park, S.Y.; Wong, S.S.; Pestka, J.J. Modulation of nitric oxide, hydrogen peroxide and cytokine production in a clonal macrophage model by the trichothecene vomitoxin (deoxynivalenol). Toxicology 1998, 125, 203-214. [PubMed]

39. Cai, H.; Harrison, D.G. Endothelial dysfunction in cardiovascular diseases: The role of oxidant stress. Circ. Res. 2000, 87, 840-844. [CrossRef] [PubMed]

40. Zielke, H.R.; Zielke, C.L.; Ozand, P.T. Glutamine: A major energy source for cultured mammalien cells. Fed. Proc. 1984, 43, 121-125. [PubMed]

41. Curi, R.; Lagranha, C.J.; Doi, S.Q.; Sellitti, D.F.; Procopio, J.; Pithon-Curi, T.C.; Corless, M.; Newsholme, P. Molecular mechanisms of glutamin action. J. Cell Physiol. 2005, 204, 392-401. [CrossRef] [PubMed]

42. Bourges, I.; Ramus, C.; Mousson de Camaret, B.; Beugnot, R.; Remacle, C.; Cardol, P.; Hofhaus, G.; Issartel, J.P. Structural organization of mitochondrial human complex I: Role of the ND4 and ND5 mitochondria-encoded subunits and interaction with prohibitin. Biochem. J. 2004, 383, 491-499. [CrossRef] [PubMed]

43. DeBerardinis, R.J.; Mancuso, A.; Daikhin, E.; Nissim, I.; Yudkoff, M.; Wehrli, S.; Thompson, C.B. Beyond aerobic glycolysis: Transformed cells can engage in glutamine metabolism that exceeds the requirement for protein and nucleotide synthesis. PNAS 2007, 104, 19345-19350. [CrossRef] [PubMed]

44. Vander Heiden, M.G.; Cantley, L.C.; Thompson, C.B. Understanding the Warburg effect: The metabolic requirements of cell proliferation. Science 2009, 324, 1029-1033. [CrossRef] [PubMed]

45. Bannert, E.; Tesch, T.; Kluess, J.; Frahm, J.; Kersten, S.; Kahlert, S.; Renner, L.; Rothkötter, H.-J.; Dänicke, S. Metabolic and Hematological consequences of dietary deoxynivalenol interacting with systemic Escherichia coli lipopolysaccharide. Toxins 2015, 7, 4773-4796. [CrossRef] [PubMed]

46. Lv, Z.; Zhang, X.; Liu, L.; Chen, J.; Nie, Z.; Sheng, Q.; Zhang, W.; Jiang, C.; Yu, W.; Wang, D.; et al. Characterization of a gene encoding prohibitin in silkworm, Bombyx Mori. Gene 2012, 502, 118-124. [CrossRef] [PubMed]

47. Liemburg-Apers, D.C.; Wagenaars, J.A.L.; Smeitink, J.A.M.; Willems, P.H.G.M.; Koopman, W.J.H. Acute stimulation of glucose influx upon mitoenergetic dysfunction requires LKB1, AMPK, Sirt2 and mTOR-RAPTOR. J. Cell Sci. 2011, 129, 4411-4423. [CrossRef] [PubMed]

48. Nijtamns, L.G.; de Jong, L.; Artal Sanz, M.; Coates, P.J.; Berden, J.A.; Back, J.W.; Muijsers, A.O.; van der Spek, H.; Grivell, L.A. Prohibitins act as a membrane-bound chaperone for the stabilization of mitochondrial proteins. EMBO J. 2000, 19, 2444-2451. [CrossRef] [PubMed]

49. Kathiria, A.S.; Butcher, L.D.; Feagins, L.A.; Souza, R.F.; Boland, C.R.; Theiss, A.L. Prohihitin 1 modulates mitochondrial stress-related autophagy in human colonic epithelial cells. PLoS ONE 2012, 7, e31231. [CrossRef] [PubMed]

50. Merkwirth, C.; Langer, T. Prohibitin function within mitochondria: Essential roles for cell proliferation and cristae morphogenesis. BBA-Mol. Cell. Res. 2009, 1793, 27-32. [CrossRef] [PubMed]

51. Jiang, L.; Dong, P.; Zhang, Z.; Li, C.; Li, Y.; Li, X.; Wu, Z.; Guo, S.; Mai, S.; Xia, D.; et al. Akt phosphorylates Prohibitin 1 to mediate its mitochondrial localization and promote proliferation of bladder cancer cells. Cell Death Dis. 2015, 6, e1660. [CrossRef] [PubMed] 
52. Strub, G.M.; Paillard, M.; Liang, J.; Gomez, L.; Allegood, J.C.; Hait, N.C.; Maceyka, M.; Price, M.M.; Chen, Q.; Simpson, D.C.; et al. Sphingosine-1-phosphate produced by sphingosine kinase 2 in mitochondria interacts with prohibitin 2 to regulate complex IV assembly and respiration. FASEB J. 2011, 25, 300-312. [CrossRef] [PubMed]

53. Schleicher, M.; Shepherd, B.R.; Suarez, Y.; Fernandez-Hernando, C.; Yu, J.; Pan, Y.; Acevedo, M.L.; Shadel, G.S.; Sessa, W.C. Prohibitin-1 maintains the angiogenic capacity of endothelial cells by regulating mitochondrial function and senescence. J. Cell Biol. 2008, 180, 101-112. [CrossRef] [PubMed]

54. Steglich, G.; Neupert, W.; Langer, T. Prohibitins regulate membrane protein degradation by the m-AAA protease in mitochondria. Mol. Cell. Biol. 1999, 19, 3435-3442. [CrossRef] [PubMed]

55. Steube, K.G.; Koelz, A.L.; Uphoff, C.C.; Drexler, H.G.; Kluess, J.; Steinberg, P. The necessitiy of identity assessment of animal intestinal cell lines: A case report. Cytotechnology 2012, 64, 373-378. [CrossRef] [PubMed]

56. Schierack, P.; Nordhoff, M.; Pollmann, M.; Weyrauch, K.D.; Amasheh, S.; Lodemann, U.; Jores, J.; Tachu, B.; Kleta, S.; Blikslager, A.; et al. Characterization of a porcine intestinal epithelial cell line for in vitro studies of microbial pathogenesis in swine. Histochem. Cell Biol. 2006, 125, 293-305. [CrossRef] [PubMed]

57. Berschneider, H.M. Development of normal cultured small intestinal epithelial cell lines which transport $\mathrm{Na}$ and $\mathrm{Cl}$ (Abstract). Gasteroenterology 1989, 96, A41.

58. Edgar, R.; Domrachev, M.; Lash, A. Gene Expression Omnibus: NCBI gene expression and hybridization array data repository. Nucleic Acids Res. 2002, 30, 207-210. [CrossRef] [PubMed]

59. Kauffmann, A.; Gentleman, R.; Huber, W. arrayQualityMetrics-A bioconductor package for quality assessment of microarray data. Bioinformatics 2009, 25, 415-416. [CrossRef] [PubMed]

60. Bourgon, R.; Gentleman, R.; Huber, W. Independent filtering increases detection power for high-throughput experiments. Proc. Natl. Acad. Sci. USA 2010, 107, 9546-9551. [CrossRef] [PubMed]

61. Storey, J.; Tibshirani, R. Statistical significance for genomewide studies. Proc. Natl. Acad. Sci. USA 2003, 100, 9440-9445. [CrossRef] [PubMed]

62. Pfaffl, M.W. A new mathematical model for relative quantification in real-time RT-PCR. Nucleic Acid Res. 2001, 29, e45. [CrossRef] [PubMed]

63. Müller, A.; Stellmacher, A.; Freitag, C.E.; Landgraf, P.; Dieterich, D.C. Monitoring Astrocytic Proteome Dynamics by Cell Type-Specific Protein Labeling. PLoS ONE 2015, 21, e0145451. [CrossRef] [PubMed]

64. Dieterich, D.C.; Lee, J.J.; Link, A.J.; Graumann, J.; Tirell, D.A.; Schuman, E.M. Labeling, detection and identification of newly synthesized proteomes with bioorthogonal noncanonical amino acid tagging. Nat. Protoc. 2007, 2, 532-540. [CrossRef] [PubMed]

65. Landgraf, P.; Antileo, E.R.; Schumann, E.M.; Dieterich, D.C. BONCAT: Metabolic labeling, click chemistry, and affinity purification of newly synthesized proteoms. Meth. Mol. Biol. 2014, 1266, 199-215. 